\title{
Measure Guideline: Air Sealing Attics in Multifamily Buildings
}

C. Otis and S. Maxwell

Consortium for Advanced Residential Buildings (CARB)

June 2012 


\section{NOTICE}

This report was prepared as an account of work sponsored by an agency of the United States government. Neither the United States government nor any agency thereof, nor any of their employees, subcontractors, or affiliated partners makes any warranty, express or implied, or assumes any legal liability or responsibility for the accuracy, completeness, or usefulness of any information, apparatus, product, or process disclosed, or represents that its use would not infringe privately owned rights. Reference herein to any specific commercial product, process, or service by trade name, trademark, manufacturer, or otherwise does not necessarily constitute or imply its endorsement, recommendation, or favoring by the United States government or any agency thereof. The views and opinions of authors expressed herein do not necessarily state or reflect those of the United States government or any agency thereof.

Available electronically at http://www.osti.gov/bridge

Available for a processing fee to U.S. Department of Energy

and its contractors, in paper, from:

U.S. Department of Energy

Office of Scientific and Technical Information

P.O. Box 62

Oak Ridge, TN 37831-0062

phone: 865.576 .8401

fax: 865.576 .5728

email: mailto:reports@adonis.osti.gov

Available for sale to the public, in paper, from:

U.S. Department of Commerce

National Technical Information Service

5285 Port Royal Road

Springfield, VA 22161

phone: 800.553 .6847

fax: 703.605 .6900

email: orders@ntis.fedworld.gov

online ordering: http://www.ntis.gov/ordering.htm

Printed on paper containing at least $50 \%$ wastepaper, including $20 \%$ postconsumer waste 


\title{
Measure Guideline: Air Sealing Attics in Multifamily Buildings
}

\author{
Prepared for: \\ Building America \\ Building Technologies Program \\ Office of Energy Efficiency and Renewable Energy \\ U.S. Department of Energy \\ Prepared by: \\ Casey Otis and Sean Maxwell \\ Steven Winter Associates, Inc. \\ 61 Washington Street \\ Norwalk, CT 06854 \\ of the
}

Consortium for Advanced Residential Buildings (CARB)

NREL Technical Monitor: Cheryn Engebrecht

Prepared under Subcontract No. KNDJ-0-40342-02

June 2012 
[This page left blank] 


\section{Contents}

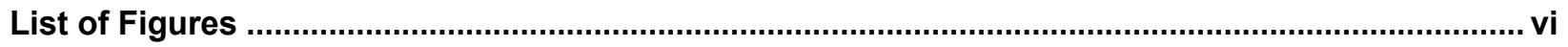

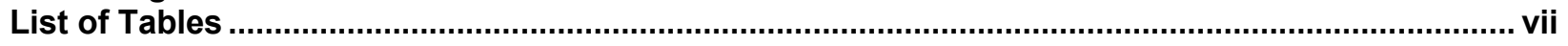

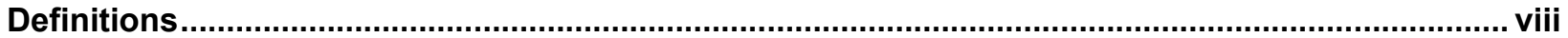

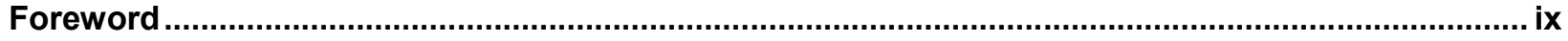

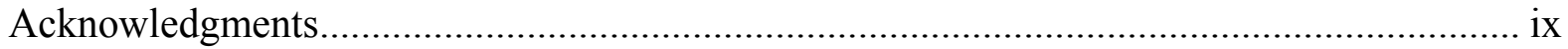

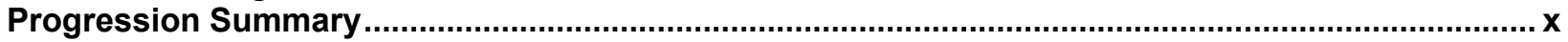

1 Introduction

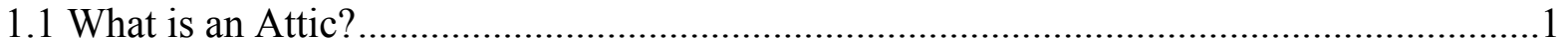

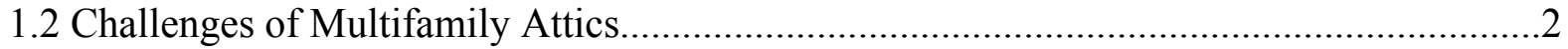

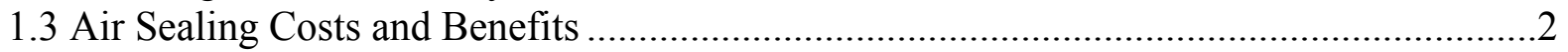

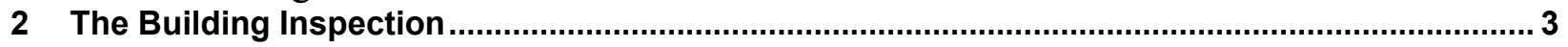

2.1 Construction Type and Access to Perform Work .............................................................

2.2 Assessing the Need for Air Sealing ....................................................................

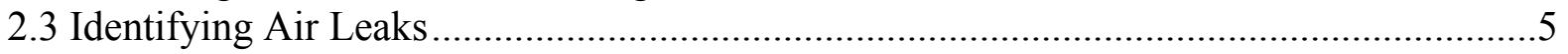

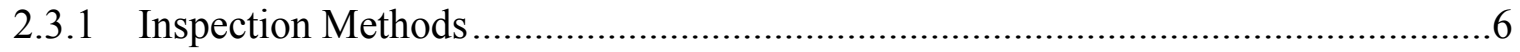

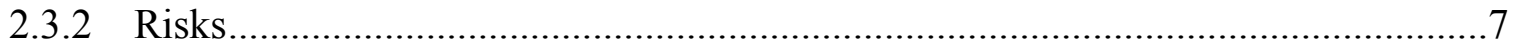

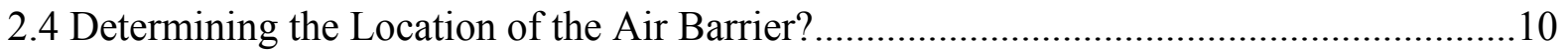

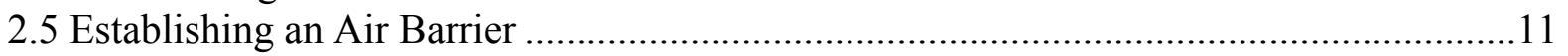

2.6 Developing an Air Sealing Work Scope ............................................................. 12

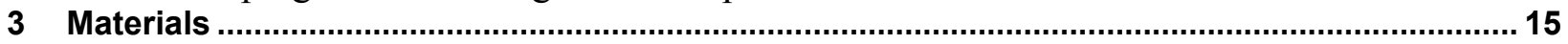

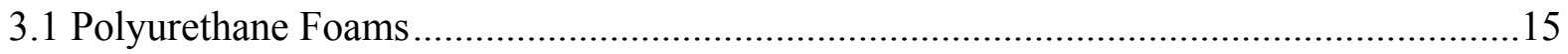

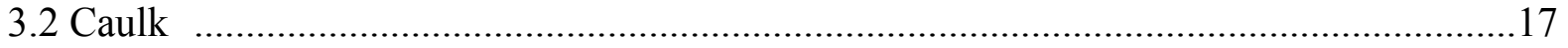

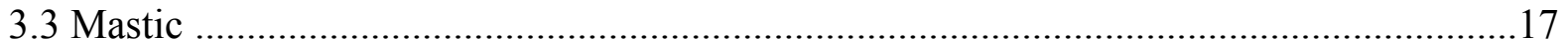

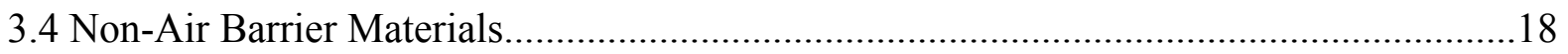

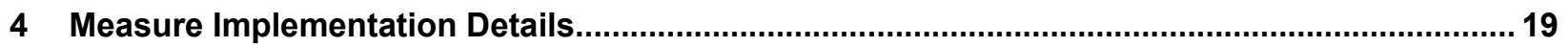

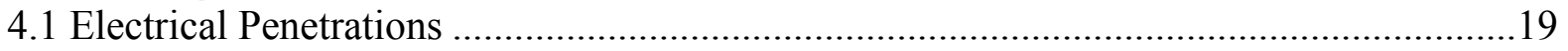

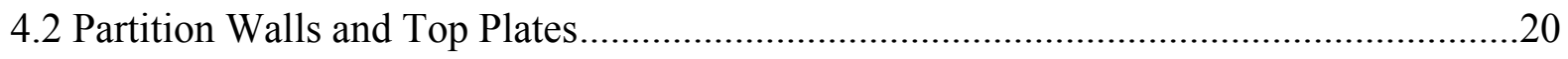

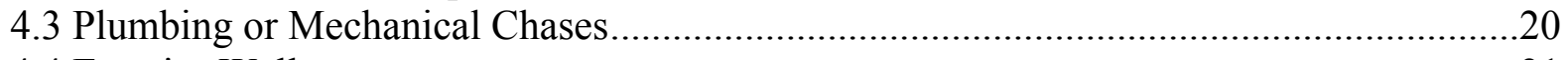

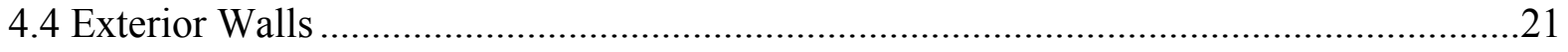

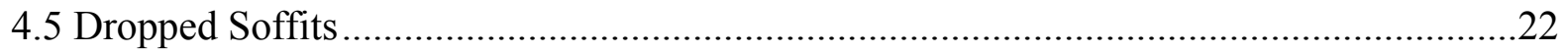

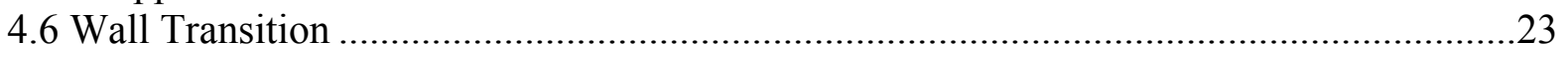

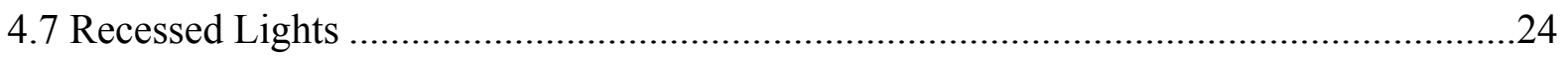

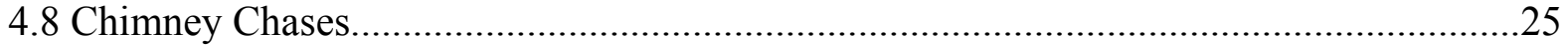

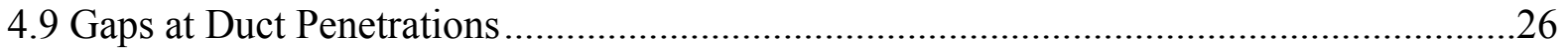

4.10 Fire-Rated Assemblies ..........................................................................................27

4.11 Access Panels and Hatches ................................................................................29

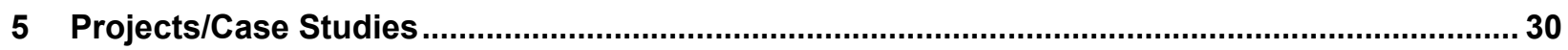

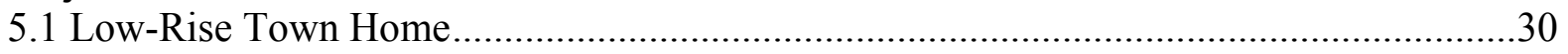

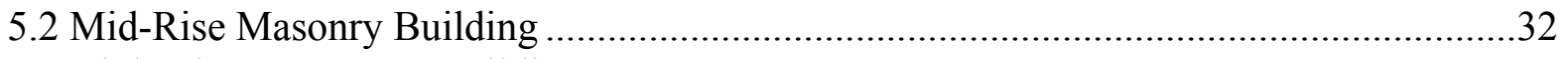

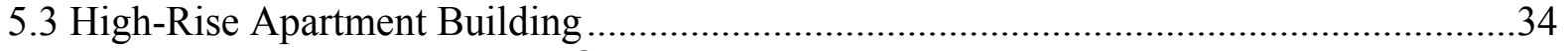

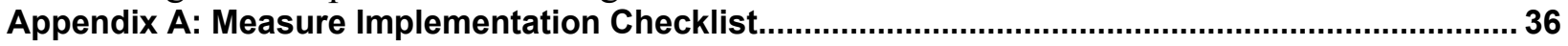

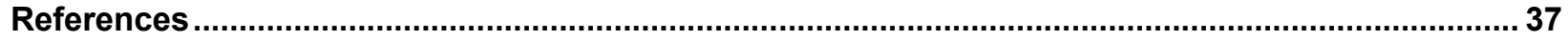




\section{List of Figures}

Figure 1. There is a wide variety of multifamily buildings............................................................ ix

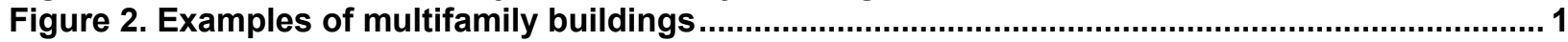

Figure 3. This complex of row houses has attics with excellent access for air sealing, as roof

trusses provide plenty of maneuvering space......................................................................... 3

Figure 4. Access to the attic in this multifamily building will be more difficult but not impossible. 3

Figure 5. This multifamily building has almost no clearance for workers to enter the attic, so the only way to properly seal the cavity is from below by removing the ceiling................................ 4

Figure 6. Dirty insulation suggests air movement. The insulation is acting as a filter. ..................... 4

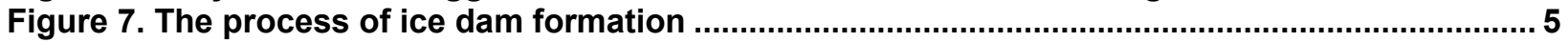

Figure 8. Without removing the attic insulation, this wall chase would have been missed .............. 6

Figure 9. Remote inspection with a borescope (from left to right): Borescope tool; Finding existing insulation; Finding major air leaks despite past insulation work. ............................................... 6

Figure 10. Using existing roof vents to investigate the roof cavity (from left to right): An existing roof vent; Vent removed; View from hand-held digital camera.

Figure 11. Using infrared imaging to detect air leaks on a cold day. The image on the right shows potential air leakage at the ceiling/wall intersection on the top floor that should be further inspected.

Figure 12. The process of mold formation due to air leakage into an attic (left). Mold found in unpitched framed roof assembly (right).

Figure 13. Accessing an attic through a cut-out in the roof (from left to right): A hole is cut with a saw; workers enter to perform air sealing; the available space in this attic affords good access.

Figure 14. Roof vent installed with properly sealed butyl membrane .........................................13

Figure 15. Air sealing junction boxes and top plate penetrations, before ceiling drywall is installed

Figure 16. Polyurethane foam applied against underside of roof deck to convert to an unvented ceiling assembly.

Figure 17. Closed-cell spray polyurethane foam quickly air seals and insulates this

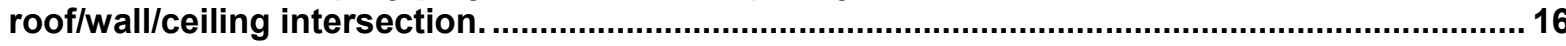

Figure 18. One-part foam effectively air seals these small irregular gaps at a duct penetration and top plate in an attic.

Figure 19. Gap sealed used one-part foam and rigid insulation board (left). Chimney flue being blocked with sheet metal and fire-rated caulk (right)........................................................... 17

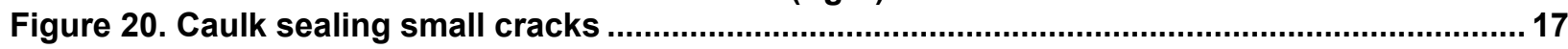

Figure 21. Mastic can be applied with a gloved hand. .................................................................... 17

Figure 22. Fibrous insulation without an air barrier easily allows the passage of building air (left). Note dirty fiberglass surrounding this attic bypass, as air passes through the insulation but dirt gets trapped (right).

Figure 23. Common leakage sites in a multifamily building attic ................................................... 19

Figure 26. Mechanical chase in attic of a mid-rise apartment building ............................................ 21

Figure 24. Sealing a common electrical penetration (left). Electrical box sealed before drywall installation (right) ............................................................................................................. 20

Figure 25. Common partition wall gap (left). Expanding foam quickly seals gaps at top plates (right).

Figure 29. Soffit with continuous drywall at ceiling in a gut-rehab project...

Figure 27. Typical leakage location at exterior wall and arrow showing path of air movement (left). Gap sealed using one-part expanding foam (right).

Figure 28. Step-by-step sequence for blocking an open soffit from attic side. .............................22

Figure 30. Recommended location of air barriers (in red) of a well-sealed soffit.............................23

Figure 31. Open stud cavity (left) and stud cavity sealed using bagged insulation and spray foam (above).

Figure 32. Air leakage at ceiling height changes, and how to air seal the cavities using bags stuffed with fiberglass. 
Figure 33. Procedure to air seal non-IC rated lights (left). Air tight recessed light label (BECRC) (right).

Figure 34. Sheetmetal blocking around chimneys Insulation dams still need to be installed.

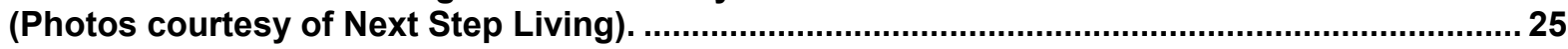

Figure 35. Necessary components for air sealing and insulating at chimney ................................26

Figure 36. Unsealed gap at duct work penetration, viewed from roof ...........................................26

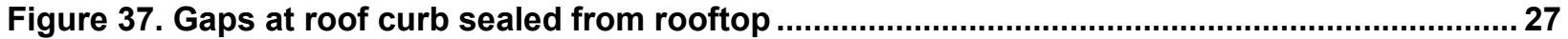

Figure 38. Caulked gap at apartment side of fan penetration (left). Sealing bath fan penetration

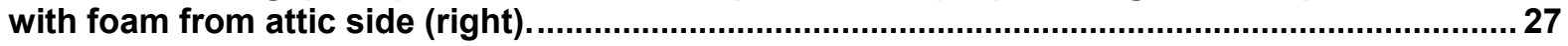

Figure 39. It is necessary to maintain fire ratings between conditioned spaces and unconditioned attics of neighboring apartments......................................................................................... 28

Figure 40. Process of sealing a hole in a fire-rated assembly between apartments .......................28

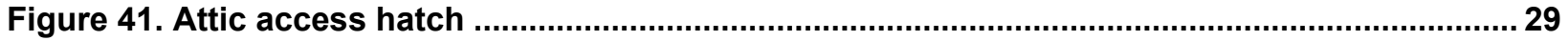

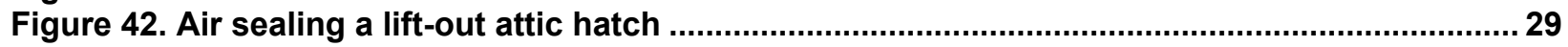

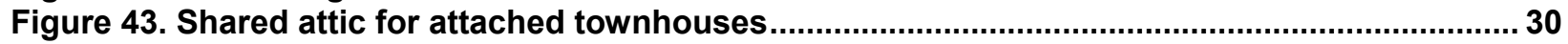

Figure 44. Addressing various attic leaks found in low-rise multifamily buildings......................... 31

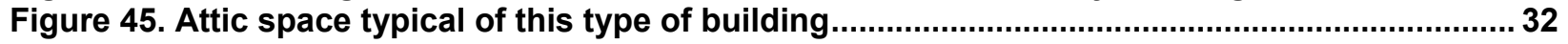

Figure 46. Accessing the attic through the roof deck to perform air sealing ..................................... 33

Figure 47. A 17-story multifamily building with large attic space .................................................. 34

Figure 48. Various air bypasses that where found during the attic inspection................................ 35

Unless otherwise noted, all figures were created by CARB.

\section{List of Tables}

Table 1. Comparison of Attic Air Leaks in Single-Family and Multifamily Buildings ....................... 5

Unless otherwise noted, all tables were created by CARB. 


\section{Definitions}

$\mathrm{AC}$

BPI

CAZ

$\operatorname{ccSPF}$

CFM

EPA

HVAC

IAQ

MSDS

Demising Wall
Air conditioning

Building Performance Institute

Combustion appliance zone

Closed-cell spray polyurethane foam

Cubic feet per minute

Environmental Protection Agency

Heating, ventilation, and air conditioning

Indoor air quality

Material Safety Data Sheet

A partition wall that separates one apartment from another or from the common area such as a public corridor 


\section{Foreword}

The goal of air sealing in buildings is to reduce the unintentional flow of air between unconditioned and conditioned space or between two independently occupied dwellings. This guide will assist when air sealing multifamily attic and roof assemblies.

This Building America Measure Guideline is intended for building owners, builders, contractors, homeowners, and other stakeholders in the multifamily industry. It explains why air sealing is desirable, explores related health and safety issues, and identifies common air leakage points in multifamily building attics. In addition, it also gives an overview of materials and techniques typically used to perform air sealing work. The guide focuses mainly on challenges found in existing buildings for a variety of building types, from low-rise wood-frame multifamily to mid- and high-rise masonry apartment buildings.

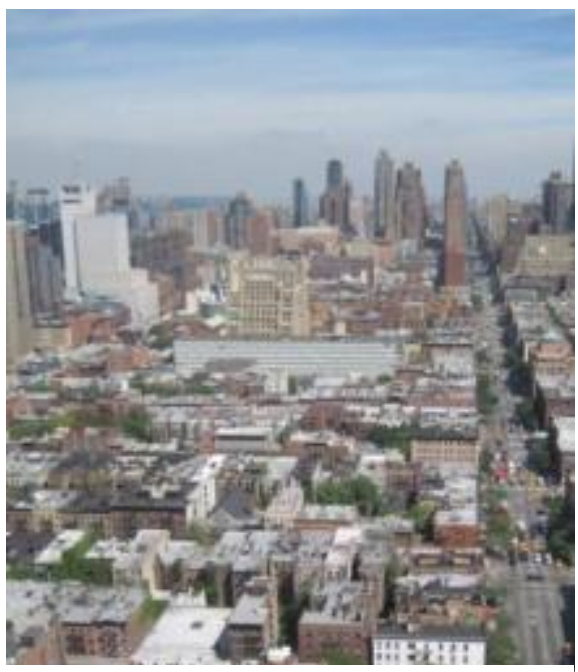

Figure 1. There is a wide variety of multifamily buildings

\section{Acknowledgments}

This guideline is the product of a collaborative effort. The authors acknowledge the funding and support of the U.S. Department of Energy's Building America Program. Special thanks to Marcelo at ASK Construction, the Puerto Rican Lutheran Housing Authority, John Boehm at L\&M Management, and Jacob Kloc at Airseal Insulation Systems. The authors also wish to thank Dave Boettcher at Next Step Living, Inc. for use of several of their photos. 


\section{Progression Summary}

Inspect the building for significant risks. Risks may include, but are not limited to:

- Structural problems

- Exposed or knob-and-tube wiring

- Severe water damage or mold problems

- Incorrect ventilation of roof cavity

- Ventilation ducts terminating in attic

- Erratic or dangerous occupants

- Asbestos or other toxic materials

If significant risks are present: DO NOT PROCEED WITH WORK

Assess the accessibility of roof cavity. If the roof cavity is not easily accessible then certain approaches to air sealing will not be possible. It may be necessary to cut additional access holes to allow full access to the attic. See "Inspections Methods" on page 9 .

Inspect the attic for any health/safety risks, including those mentioned above, and:

- Combustion appliance air intakes

- Chimneys or flues that pass through the attic

- Recessed lights that are not rated for insulation contact

- Sufficient space and floor strength to allow workers to enter safely

See "Risks" on page 10.

Determine where to establish the air barrier. Consider existing air tightness and what work would be necessary to air seal correctly. It may be necessary to move insulation to identify all locations in need of air sealing. See "Establishing an Air Barrier" on page 5.

Develop a work plan. Identify specific areas in need of air sealing and materials that will be needed. See "Materials" on page 16.

Perform air sealing work. Using appropriate materials and methods, perform all necessary air sealing work to create an air barrier system. See "Measure Implementation Details" on page 20 .

Inspect the attic to ensure that air sealing has not created any health or safety risks. Appropriate clearances to chimneys and recessed lights must be maintained. Any venting required under applicable building codes must be maintained. 


\section{Introduction}

Air leakage contributes to significant energy loss in multifamily buildings as well as to a number of building performance, comfort, and durability problems. Therefore, controlling air leakage is desirable for a number of reasons:

- It reduces the amount of energy used for heating and cooling.

- It affords better control of the indoor environment by space-conditioning equipment.

- It improves comfort by reducing drafts and balancing temperature distribution in the building.

- It inhibits the transmission of damaging moisture-laden air through building assemblies, which may prevent the decay of building components and increase the life of the building.

- It improves the effectiveness of many common insulation materials.

In multifamily buildings, the attic or roof is an important target for air sealing efforts. It is one of the most cost-effective areas to air seal because the pressures exerted by the stack effect are greatest at the top and bottom of a building. Compared to air sealing apartments, problems of access can be simpler in attics.

Though there are a wide variety of attic situations in multifamily buildings, the techniques for air sealing them should be familiar to many building professionals. This guide will provide an understanding of the importance of the different types of multifamily building attics and their unique challenges, and outlines strategies and materials used in air sealing them.
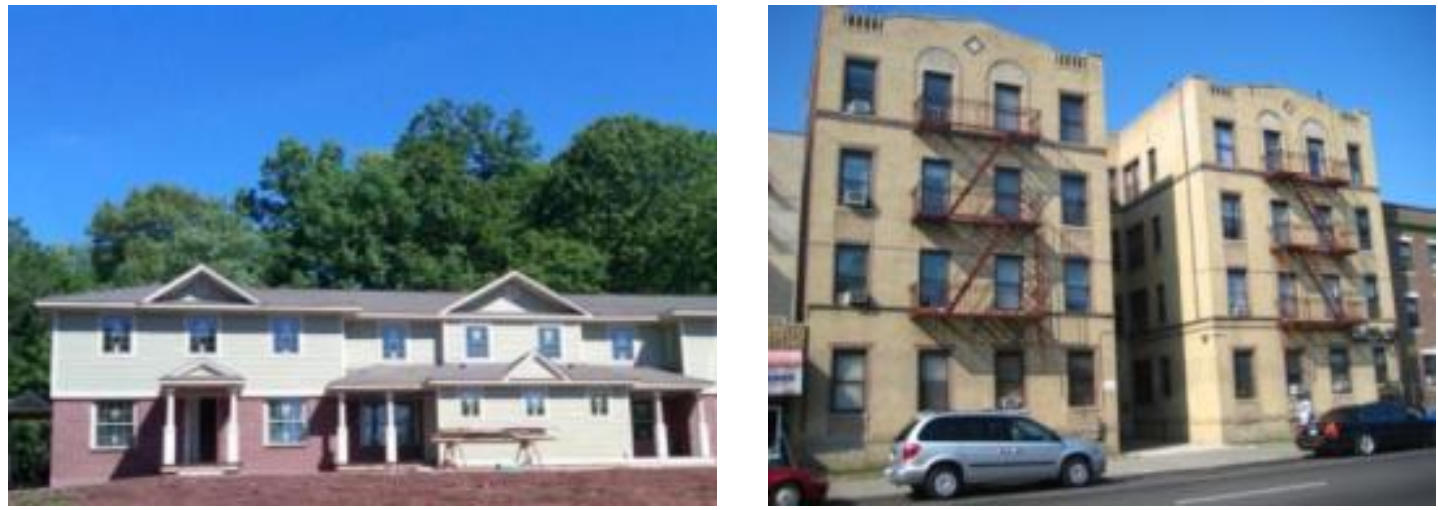

Figure 2. Examples of multifamily buildings

\subsection{What is an Attic?}

Unoccupied spaces below the roof in multifamily buildings often serve the same functions as attics in single-family homes: storage, space to run services, or simply a means to allow the roof to slope. The types of attics in multifamily building are not precisely defined, but they can be broken into three general groups:

Pitched roofs framed with trusses or rafters, usually with sufficient attic space for a worker to enter. This is typical of many newer low-rise townhomes. These are quite similar to single- 
family construction, except that they frequently include fire-rated demising walls that pass through the attic space separating the dwelling units. These attic assemblies are generally vented to the outdoors.

Un-pitched framed roof assemblies, either with or without a space between the roof and ceiling framing ("cockloft"). This type of roof assembly is commonly found in older urban row houses, including brownstones, as well as larger apartment buildings. Limited access means that these assemblies can be very difficult to air seal effectively. These roof assemblies are sometimes vented to the outdoors.

Un-pitched roof assemblies in steel and masonry buildings. There are a variety of construction types for taller multifamily buildings; some have a large attic space for mechanical and other systems, while many new residential buildings are being built with concrete planks or slabs, which may provide the finished ceiling and a roof deck as a single element.

\subsection{Challenges of Multifamily Attics}

Air sealing in multifamily attics and roof cavities is similar in principle and general methods to single family construction, but is different enough to warrant separate consideration. Some of the challenges unique to multifamily attic air sealing include:

- Construction that results in small spaces with limited access

- More stringent code requirements regarding fire protection

- Complicated ownership structures or numerous tenants

- Unique architectural details.

Although there are greater challenges involved with air sealing multifamily attics, the rewards are greater as well. These include greater savings on heating and cooling bills, improved airquality and occupant comfort, and longer building life.

\subsection{Air Sealing Costs and Benefits}

According to NREL's National Residential Efficiency Measure Database, the cost to perform air sealing work in a single-family home ranges from an average of $\$ 0.42 / \mathrm{ft}^{2}$ of conditioned area to seal to $25 \%$ leakage reduction up to $\$ 2.40 / \mathrm{ft}^{2}$ of conditioned area to seal to $60 \%$ leakage reduction. Although these values are calculated for single-family homes, they give an idea of cost ranges for similar construction low-rise multifamily buildings. (NREL)

For larger multifamily buildings, costs are dependent on the type of attic, available access, and the strategy used for air sealing. Insulation and air sealing are often performed together. Costs for air sealing an attic and installing cellulose insulation in a confined attic can range between $\$ 2.00 / \mathrm{ft}^{2}$ and $\$ 3.00 / \mathrm{ft}^{2}$ of attic area, or distributed over the larger conditioned area of the multifamily building, from $\$ 0.10 / \mathrm{ft}^{2}$ to $\$ 0.25 / \mathrm{ft}^{2}$ depending on the building area relative to the attic ceiling plane.

Research by the Canada Mortgage and Housing Corporation found a 5.7 year payback period for multifamily whole building air sealing work. This study also notes that sealing of shafts provided a better effectiveness in terms of work cost divided by energy savings, compared to work on exterior doors, windows, and general envelope caulking. (CMHC) 


\section{The Building Inspection}

A thorough inspection is the essential starting point of a successful attic air sealing project. The goals of the inspection are to:

- Assess construction type and level of access

- Identify potential safety hazards that exist or may be created by air sealing

- Choose where to establish the airtight enclosure

- Identify specific areas in need of air sealing

- Select appropriate materials to perform air sealing.

\subsection{Construction Type and Access to Perform Work}

The multifamily building stock comprises a variety of different building types, including woodframed town homes, historic row houses and high-rise apartment buildings. The construction type dictates which approach is used to air seal. Although town homes and row houses are usually categorized as single-family attached, certain examples are included under the term "multifamily" for the purposes of this guideline due to their shared attic configuration.
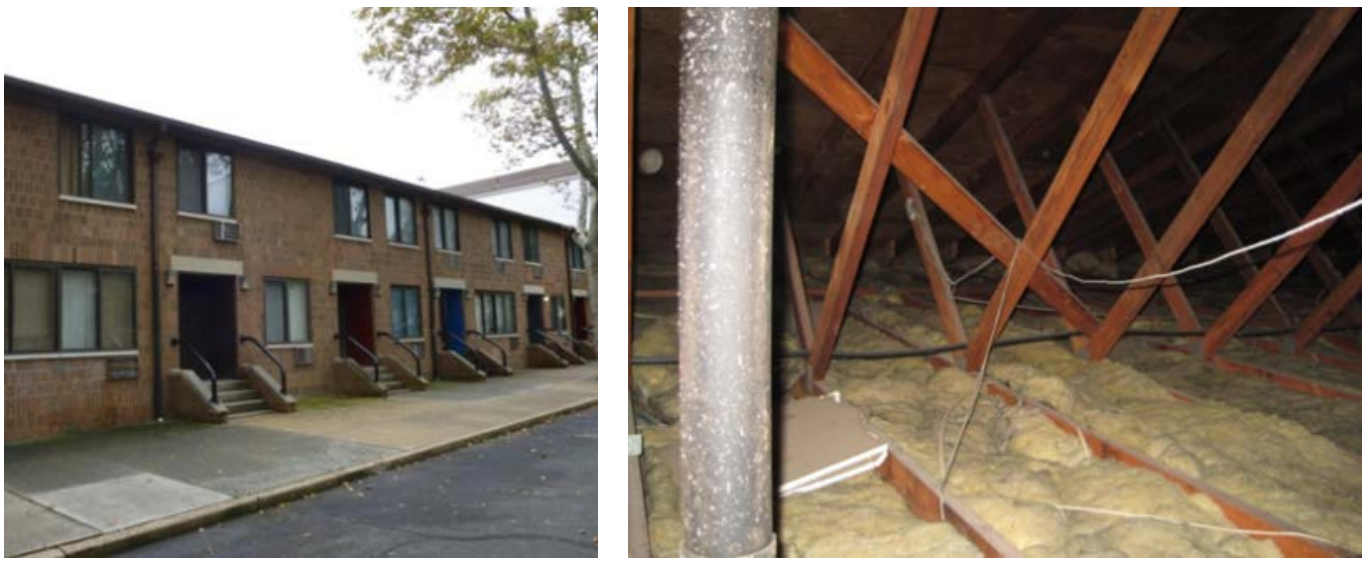

Figure 3. This complex of row houses has attics with excellent access for air sealing, as roof trusses provide plenty of maneuvering space
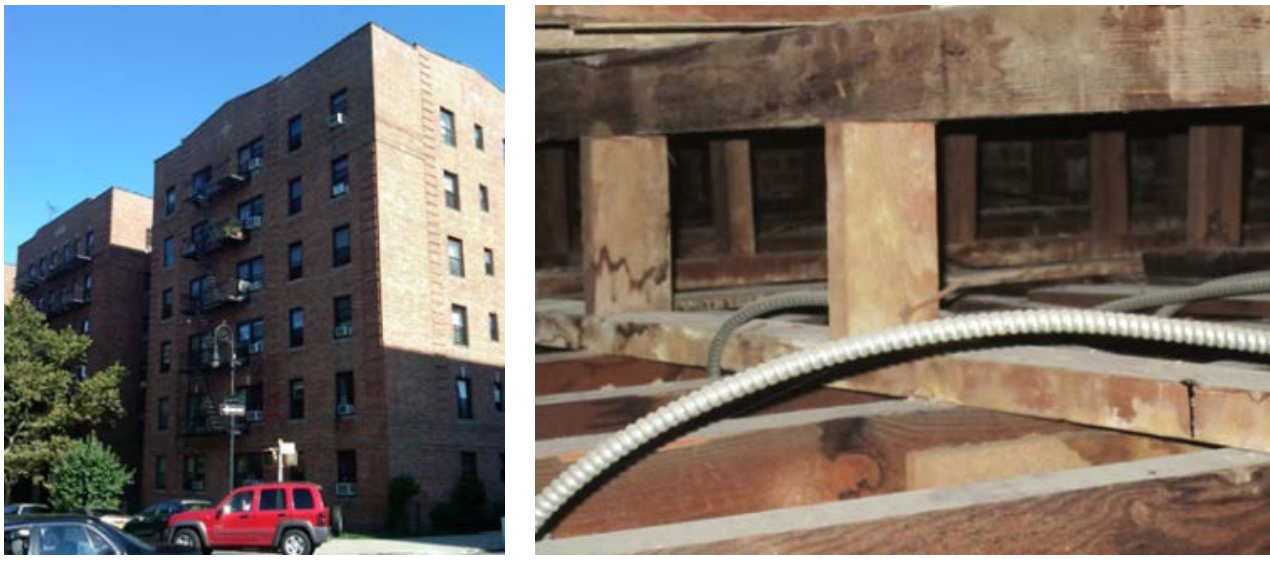

Figure 4. Access to the attic in this multifamily building will be more difficult but not impossible 

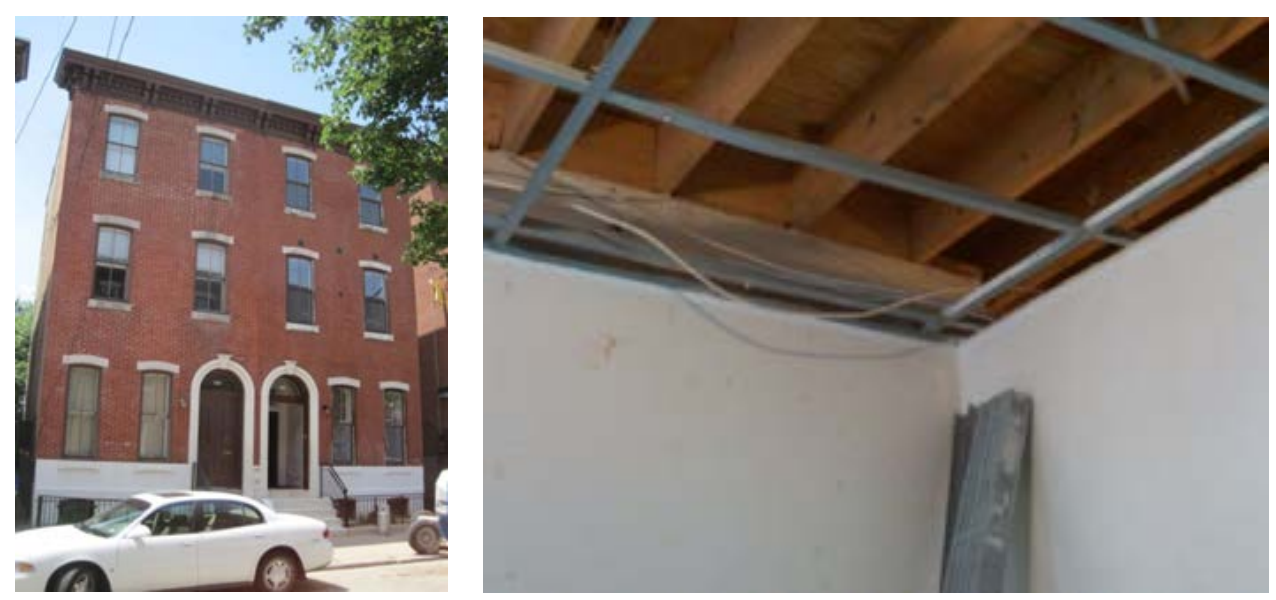

Figure 5. This multifamily building has almost no clearance for workers to enter the attic, so the only way to properly seal the cavity is from below by removing the ceiling

\subsection{Assessing the Need for Air Sealing}

Signs of air leakage into attics that should be looked for during the inspection include:

- Gaps leading from conditioned space into the attic, including around plumbing, electrical, HVAC, and chimneys

- Dirty insulation indicating air flow through or around it

- Water or moisture damage, particularly from condensation

- Ice damming or melted snow on pitched roofs during the winter.

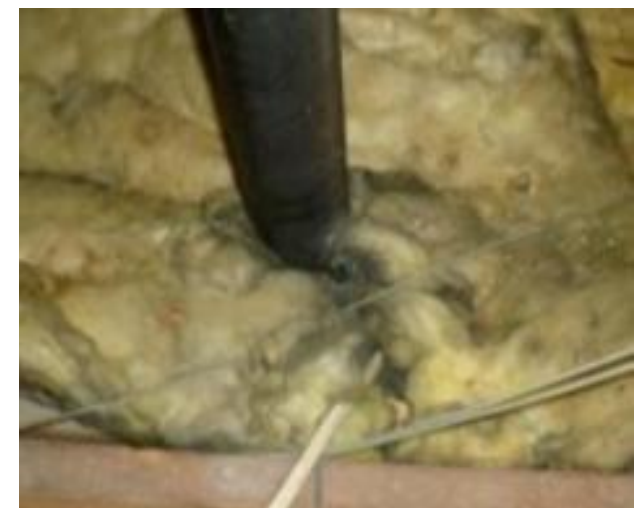

Figure 6. Dirty insulation suggests air movement. The insulation is acting as a filter

Ice damming is a common sight on older buildings with poor attic insulation and large air leaks. As shown in Figure 7 below, air passes from a building into the attic and warms the roof surface. Snow on the roof melts, and this water trickles down to the eaves. The eaves are not warmed by building heat, so water freezes on the cold surface, forming ice. As the process continues, ice dams can collect water, which backs up under shingles, causing the roof to leak. Even if the problem is not severe enough to cause leaks in the roof, the presence of large icicles and ice dams can be an indicator of major air leakage problems in an attic. 


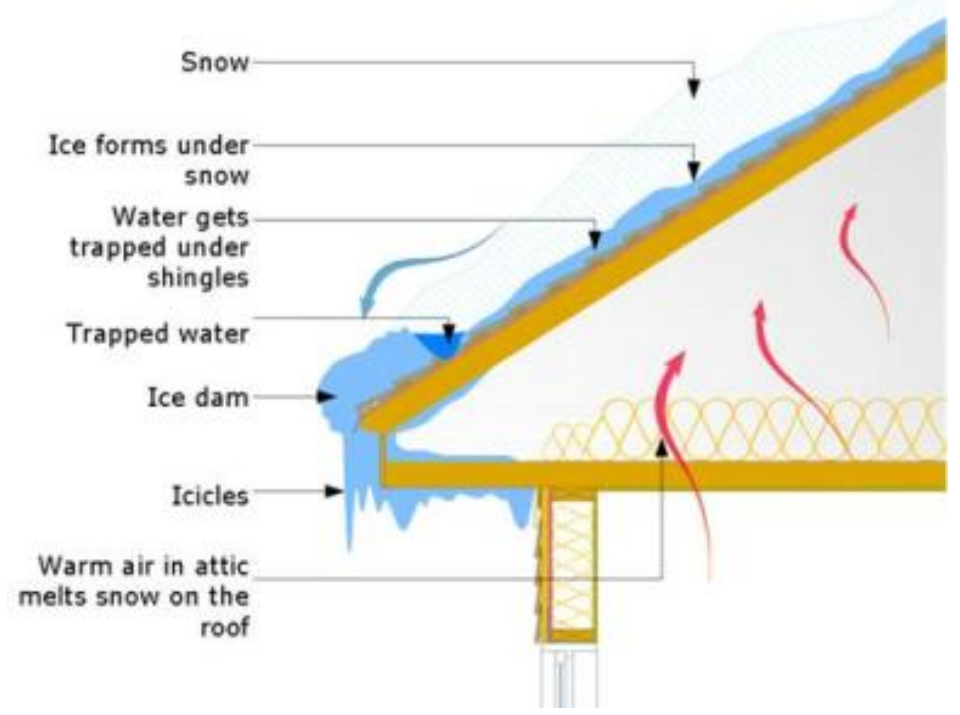

Figure 7. The process of ice dam formation

A smoke pencil is a useful tool for checking whether there is air movement at a potential air sealing site. Natural air flow caused by pressure differences between spaces will cause smoke from the pencil to drift, indicating a location in need of air sealing. Greater difference between indoor and outdoor temperatures will create greater pressure differences and more airflow.

Air sealing multifamily buildings can be similar to single-family homes, but some key differences are shown below.

Table 1. Comparison of Attic Air Leaks in Single-Family and Multifamily Buildings

\begin{tabular}{|l|l|}
\hline $\begin{array}{c}\text { Attic leaks common in both single-family and } \\
\text { multifamily buildings }\end{array}$ & $\begin{array}{c}\text { Attic leaks more unique to multifamily } \\
\text { buildings }\end{array}$ \\
\hline - Ceiling height changes/soffits & \\
- Exterior walls & - Gaps at roof fan penetrations \\
- Partition wall top plates & - Roof fan ductwork (centralized \\
- Chimneys & exhaust system) \\
- Dropped soffits in kitchens and bathrooms & - Trash chutes \\
- Plumbing, electrical and mechanical & - Fire-rated demising walls \\
- penetrations & - Attic access panels for service \\
- Recessed lights & - Plumbing or mechanical chases \\
- Attic hatches & - Elevator shaft \\
\hline
\end{tabular}

\subsection{Identifying Air Leaks}

Another goal of the inspection is to identify specific sites where leakage is occurring and to determine how to seal them. In order to locate all gaps, it will often be necessary to remove or shift insulation that is already installed. It is important to inspect as much of the attic as is accessible to avoid missing leakage sites or potential complicating factors. 

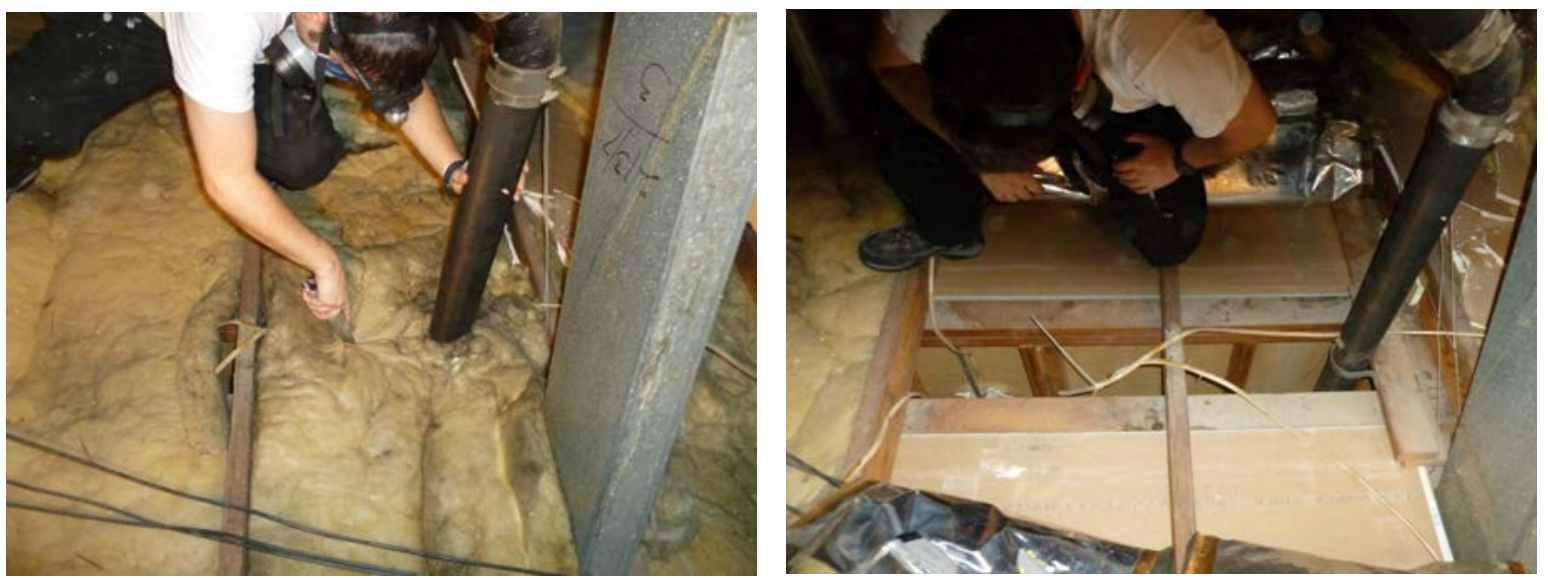

Figure 8. Without removing the attic insulation, this wall chase would have been missed

\subsubsection{Inspection Methods}

Because not all multifamily buildings allow easy access to attic or roof cavity space, performing a thorough inspection may be difficult. Options for inspecting inaccessible spaces may include remote inspection with a borescope, cutting access holes in the ceiling or roof, and infrared thermography.

Remote inspection with a borescope - A borescope is a camera mounted on a long flexible conduit that can be used to inspect inaccessible areas through a small hole. Sometimes a hole can be drilled in a low-visibility spot, such as in the ceiling of a closet, and then patched without cosmetic refinishing.
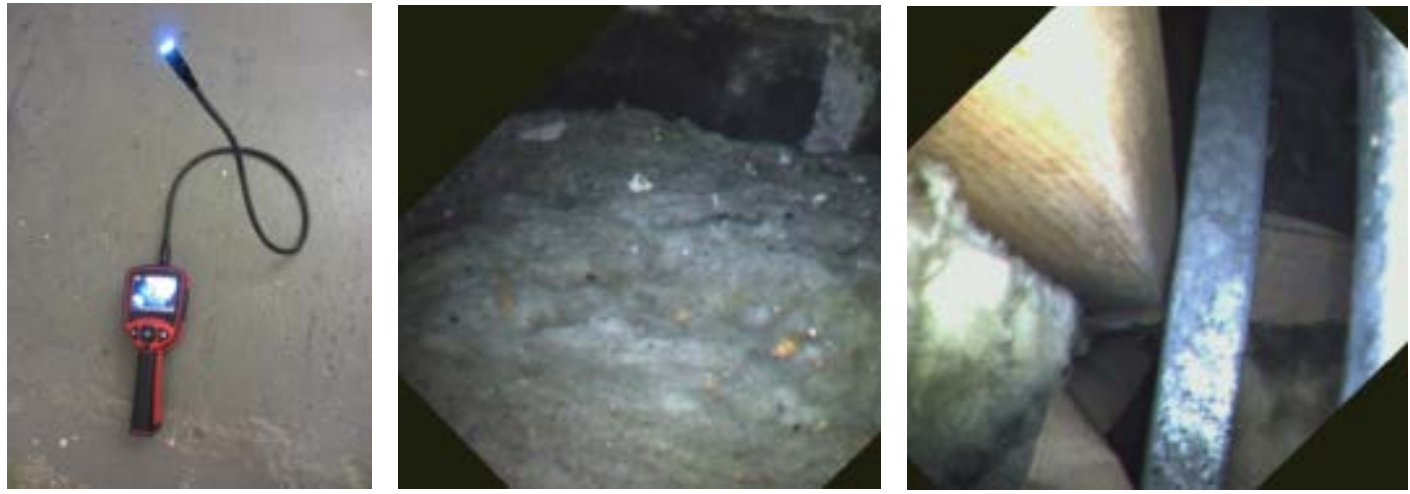

Figure 9. Remote inspection with a borescope (from left to right): Borescope tool; finding existing insulation; finding major air leaks despite past insulation work.

Cut access holes in the ceiling - It may be necessary to cut access holes into the ceiling of apartments or common spaces to allow inspection and entry into the attic space. Care should be taken to avoid damaging structural members, electrical services or plumbing pipes running in the ceiling. Again, low-visibility spots like closets may provide an access point without much disturbance to tenants.

Cut access holes in the roof - It may be possible to remove a fan or vent from the roof to allow visual inspection or access to the attic. Make sure to turn off any power to a fan first, and replace 
all covers afterwards to prevent water leaks. If the roof is to be replaced anyway, it may be possible to cut holes in the roof and patch them temporarily.
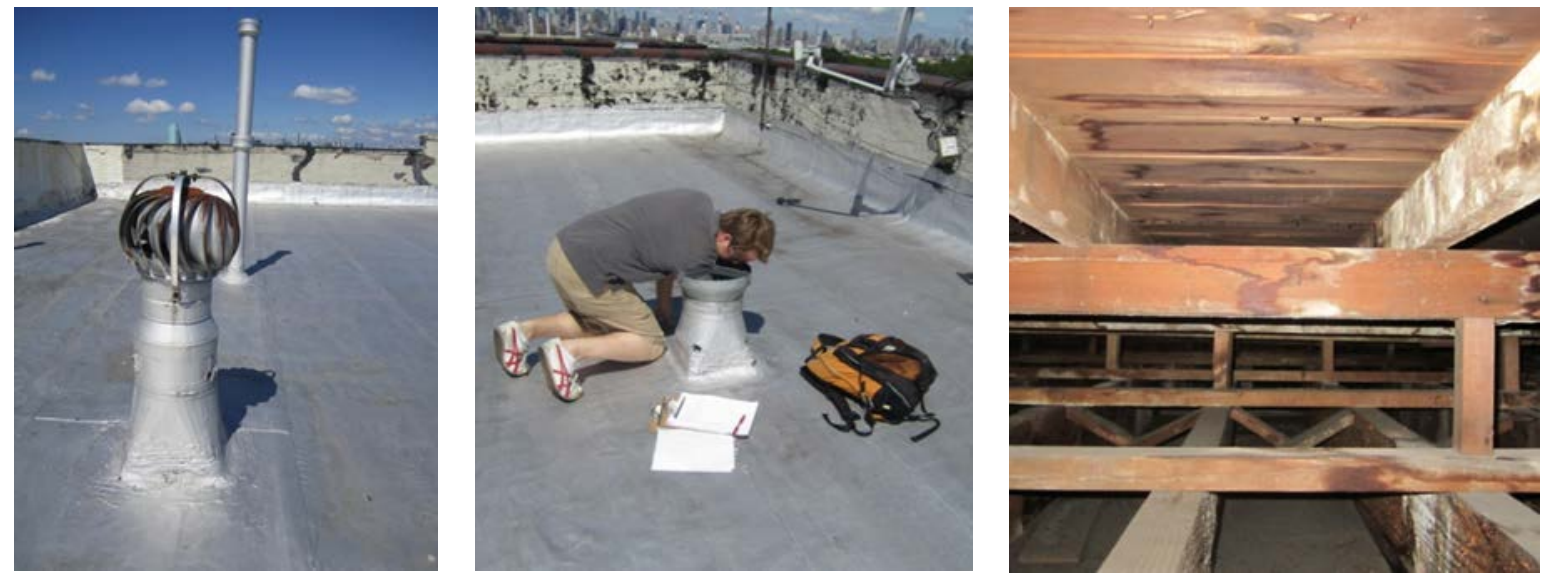

Figure 10. Using existing roof vents to investigate the roof cavity (from left to right): an existing roof vent; vent removed; view from hand-held digital camera

Infrared thermography - Infrared pictures that show temperature differences between surfaces can be a useful tool for identifying air leaks because air leaks will tend to change the temperature of the surrounding area. It is much easier to locate leaks if there is a significant temperature difference between indoors and outdoors, so a temperature difference of $20^{\circ} \mathrm{F}$ or more is advisable. As seen in the infrared image below, exterior walls which leak air into the attic will show cold spots where they meet the attic plane.
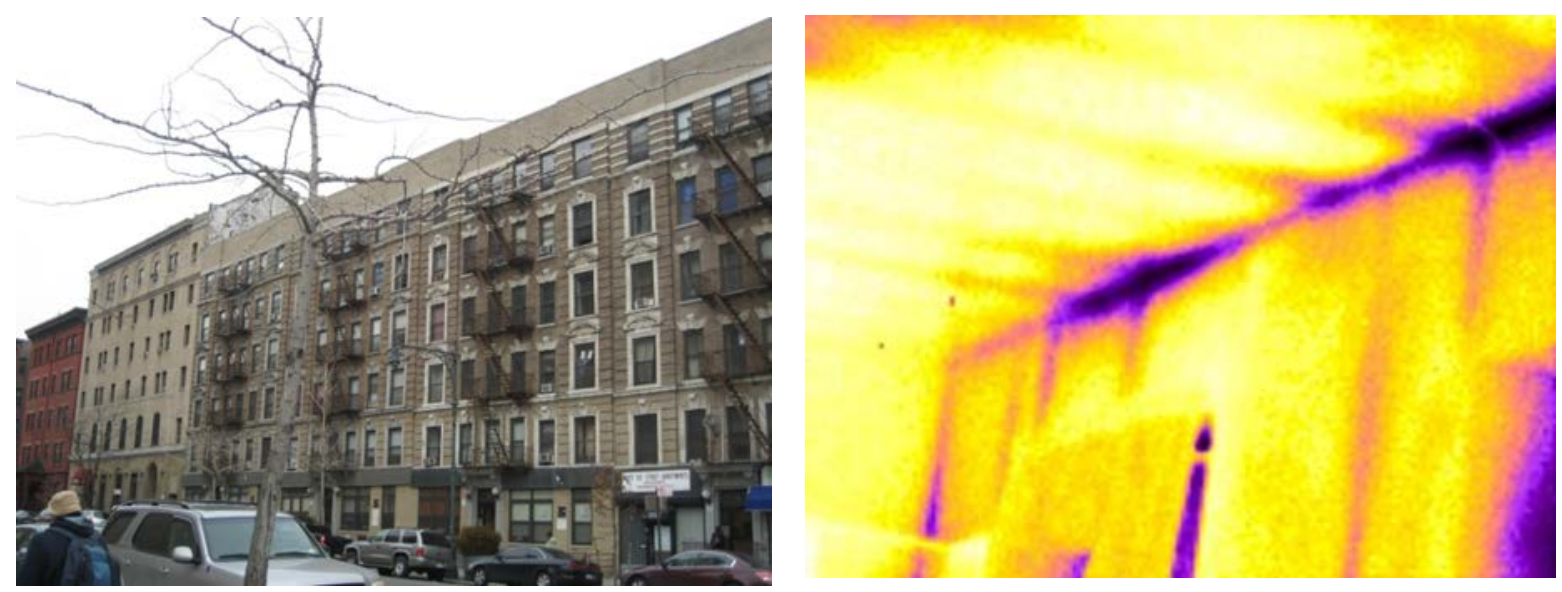

Figure 11. Using infrared imaging to detect air leaks on a cold day. The image on the right shows potential air leakage at the ceiling/wall intersection on the top floor that should be further inspected.

\subsubsection{Risks}

During the inspection, it is important to check for problems or hazards that may be created or made worse by air sealing and related work such as insulation. These can be durability issues, hazards to the occupants and/or the workers or all of the above. If any of these risks are found, 
they should be addressed by a qualified professional before air sealing work continues. Problems that may be affected or caused by air sealing work include:

Carbon Monoxide - It is extremely important that air sealing work not interfere with the proper operation of combustion appliances. Although attics in most multifamily buildings do not have combustion appliances installed in them, if they do, it is important to ensure that work does not interfere with combustion air or venting of the combustion appliance. Insufficient air for combustion can result in the production of carbon monoxide, which can be deadly. Chimneys or make up air intakes passing through attics should be treated separately from the air sealing scope of work. BPI Combustion Safety Protocols ${ }^{1}$ should be followed for any building that has combustion appliances.

Bulk Water Leaks - Moisture in attics can be very damaging to the roof structure, and it can enter in a variety of ways. Each source must be identified and eliminated before air sealing work is begun. Some possible sources are a leak in the roof and ice damming

Condensation - Air leaks in the ceiling into the roof cavity can transport moisture from humid indoor air into the attic. In addition, incorrect venting of an appliance (dryer, dehumidifier, etc.) or exhaust fan can result in humid air being dumped into the attic space. Because insulation prevents heat from the indoors from warming roof surfaces, the resulting cold roof provides a ready surface on which this moisture can condense. The combination of insulation and a leaky ceiling provide a recipe for damaging condensation. This is why insulating a roof without air sealing is very ill-advised.

Most attics in multifamily buildings are vented, but some are not. All venting shares the same goal: to remove excess moisture from the attic space and prevent damage to the roof structure. Many roof assemblies require venting by current code, and if air sealing and insulation work is undertaken, it may be necessary to add venting to meet code requirements.

Some types of roofs, such as an unvented ceiling assembly, forgo vents entirely because they eliminate any dead air space between the insulation and the roof surface, and they incorporate vapor barriers that prevent moisture diffusion into the enclosed cavity. An example of this is spray foam applied to the underside of a roof deck. At sufficient thickness, the spray foam acts as a vapor barrier, an air barrier, and a thermal barrier all in one, and venting of the roof deck for moisture reasons is unnecessary. Certain codes allow this type of assembly, while some do not.

Asbestos - Asbestos was once widely used in building materials/products as a fire resistant insulation. When intact, asbestos-containing materials generally do not pose a health risk, but as materials deteriorate with age, fibers can become airborne and pose an increased health risk. If potential asbestos building materials are found during the attic inspection, have a certified professional inspect these materials and remove, if needed. For further information, refer to www.epa.gov/asbestos.

${ }^{1}$ www.bpi.org/documents/Gold_Sheet.pdf 
Mold - the presence of mold indicates an existing moisture problem in the building. Some types of mold are toxic. If found in significant quantities mold should be addressed by a qualified professional before air sealing work is performed.
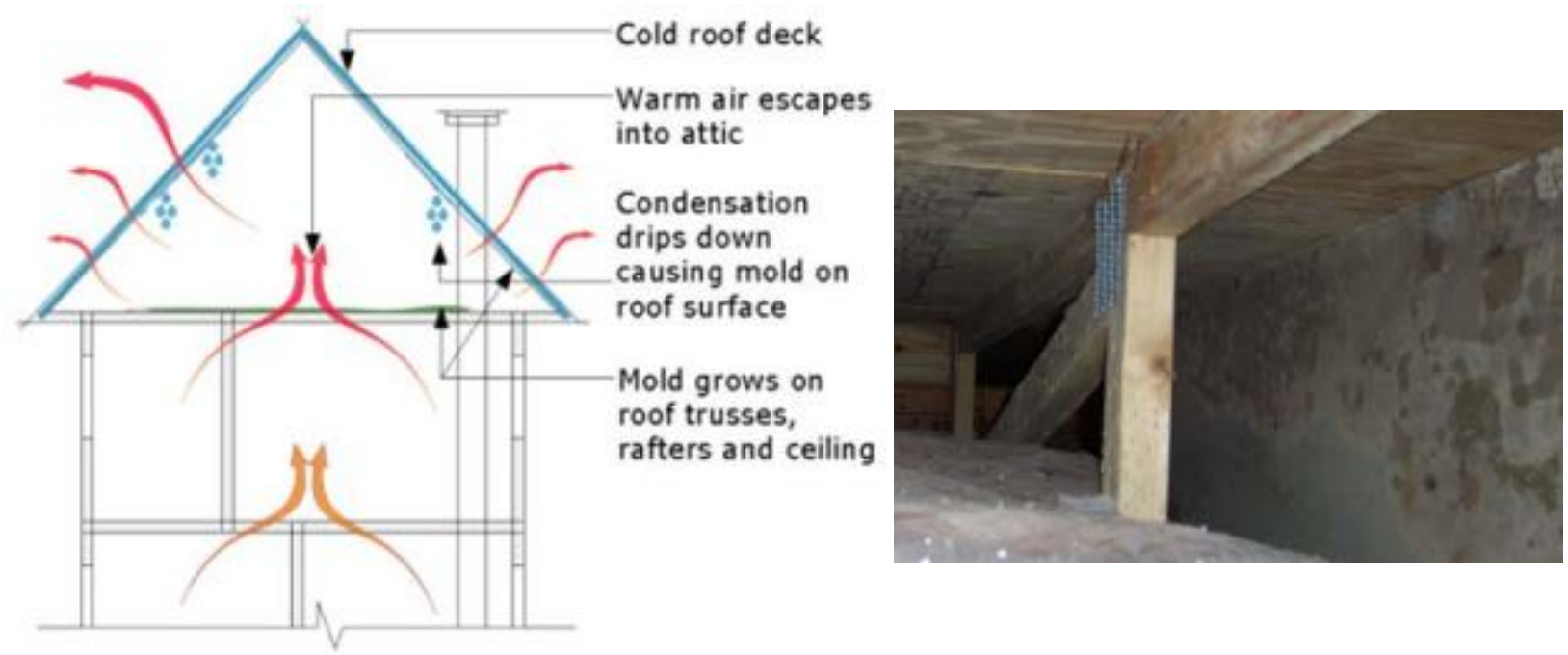

Figure 12. The process of mold formation due to air leakage into an attic (left). Mold found in unpitched framed roof assembly (right).

\section{Mold}

Mold can be found in many multifamily building attics and can be a health hazard to building occupants as well as workers. When widespread or locally severe mold is encountered, retrofit work must not begin until the source of the mold is identified and eliminated. Severe mold problems should be dealt with by a mold remediation contractor, and any problems such as roof leaks which are contributing to mold growth should be fixed before air sealing is performed.

\section{Why does mold form?}

Mold spores are present everywhere and the potential for growth always exists, but mold can be controlled by controlling moisture. The presence of mold is usually an indicator of a larger building performance problem, but the root cause of mold growth is always the presence of moisture.

\section{Get rid of moisture and get rid of mold.}

Determine the source of moisture and whether it requires outside help. Is there condensation due to humid air leaking from apartments? Is there inadequate roof ventilation or a leak in the roof? Is it due to incorrect ventilation such as a dryer or bathroom vent dumping moistureladen air to the attic?

\section{Resources}

The United States Environmental Protection Agency has many resources concerning mold and mold remediation. The following resource is a useful introduction:

http://www.epa.gov/mold/pdfs/moldremediation.pdf. Learn about recommended protective equipment when dealing with minor mold issues: http:/www.epa.gov/mold/whattowear.html 
Lead Paint - In older buildings (pre-1978), if entering the attic by opening the ceiling below, be aware of the potential for lead paint. A lead-safe certified contractor is required to handle the proper removal of materials with lead-based paint. For further information on how to check for and handle the remove of lead paint in a building, refer to www.epa.gov/lead.

Fire Hazards - Some areas are more difficult to air seal safely and effectively, and require special attention and materials. These include:

- Chimney or exhaust flues passing through attic space: Sufficient clearance (depending on jurisdiction) must be maintained between chimneys and combustible materials.

- Recessed lighting - Lights rated for insulation contact (IC Rated) can be air sealed directly and insulation placed directly on and around them. Non-IC rated lights require a minimum of 3" clearance to insulation. Since these can be a significant leakage pathway, fabricating an enclosure around the device is worthwhile. Typically gypsum board, sheet metal, or another rigid fire-resistant material can be used.

Personal Safety - Air sealing work also has the potential to be dangerous to those performing the work. Workers must wear appropriate safety equipment for the materials they are working with. This may range from gloves when working with caulk to a bodysuit with a full face respirator when spraying polyurethane foam. For kneeling work, kneepads make work much more comfortable.

When working in attics there is often a risk of falling through the finished ceiling below. The weight of workers and equipment should only be supported on adequate structural members, never on the ceiling. If insulation has been installed, it may be impossible to see where ceiling joists are located.

\subsection{Determining the Location of the Air Barrier?}

Before beginning any air sealing work, it is important to conduct an inspection to determine the best location to establish an air barrier, including considering other work that may be done in the near future. The important considerations when deciding where to establish an attic air barrier are:

- Current or planned insulation location

- Airtightness of existing building materials

- Leakage points observed during the inspection and the difficulty sealing them

- The availability of access for workers.

Insulation location is an important consideration when deciding where to locate the air barrier. It is advisable to align the air barrier with the thermal barrier (insulation). Many common insulation materials, such as fiberglass and cellulose, do not significantly slow the flow of air by themselves. The performance of the insulation may be compromised by the movement of air around and through it. Unfortunately, it is often not practical or possible to install an air barrier on the upper exposed surface of ceiling insulation.

If significant roof work is to be performed, it is a good time to evaluate the location of the air and thermal barriers and to align them if they are not already. 


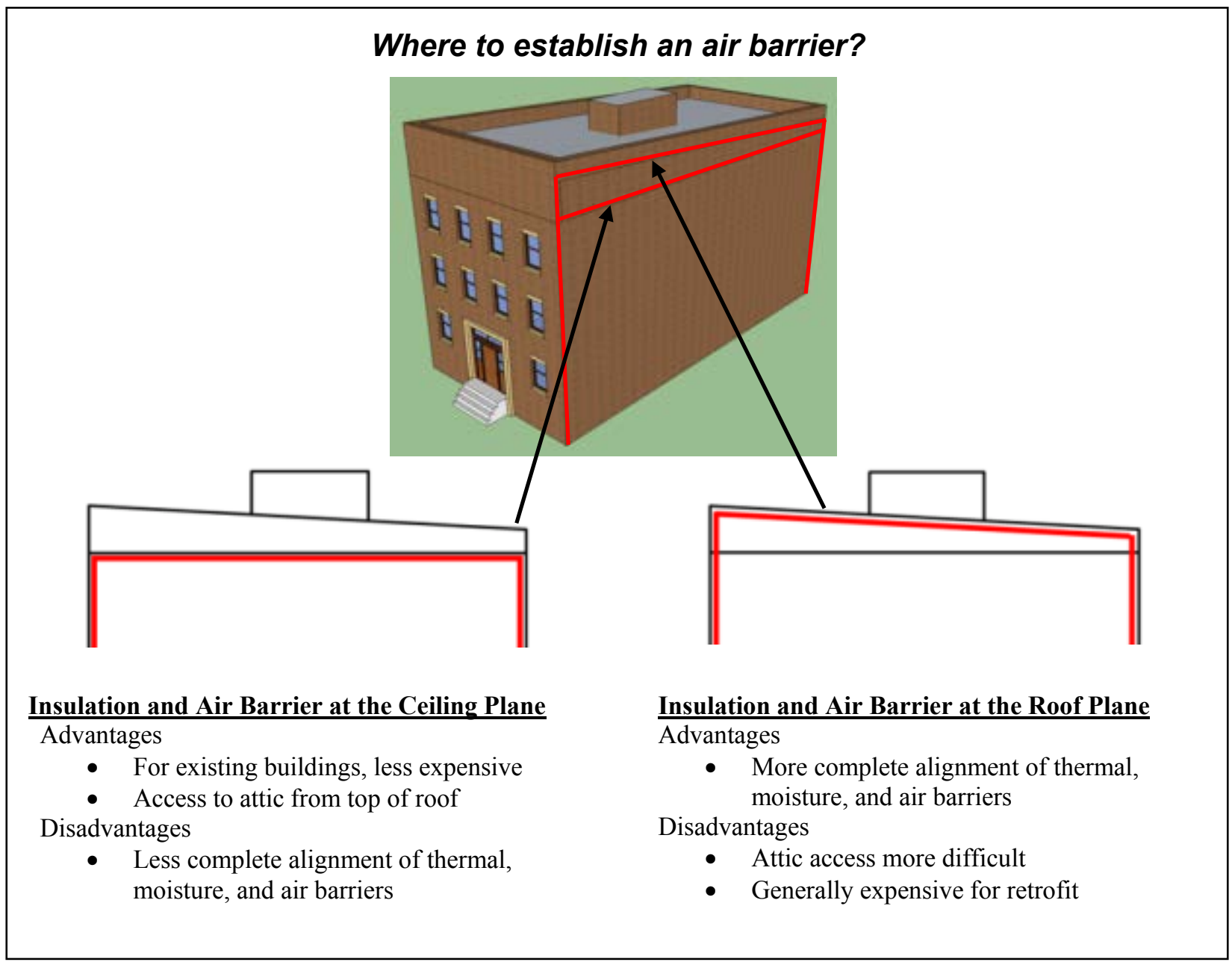

Once the best location for the air barrier is chosen, the next step is identifying specific measures. In existing buildings, this essentially consists of "stitching together" existing airtight materials such as drywall and wood studs into airtight roof or attic assemblies, and connecting these assemblies to the wall assemblies. One quickly realizes that the realization of an air barrier can be very simple or very complex, depending on construction and retrofit decisions. The difficulties of sealing a small attic with poor access and many leaks may mean that more aggressive air sealing tactics such as widespread use of spray foam become more cost effective.

\subsection{Establishing an Air Barrier}

The goal of air sealing work is to create an air-impermeable enclosure around conditioned space that will resist the unintentional passage of air to unconditioned space. A complete air barrier system can be comprised of multiple materials, and it is important to remember that the quality of the workmanship in assembling them is just as important as the materials used.

Air barrier materials are individual building materials that resist air movement. When properly assembled, they provide a continuous plane of air resistance. Properly connected building envelope assemblies - walls, roofs, etc. — combine to make a complete air barrier system, which entirely encloses the conditioned space and prevents unwanted air movement in or out. (ABAA) 
Materials commonly used to create a continuous air barrier include caulk, drywall, plywood sheathing, plastic, wood, foam boards, spray foam, and many other durable materials.

Besides providing resistance to air movement, air barriers must be long-lasting and appropriate for the job. For example, one might choose to use caulk or other semi-flexible sealant on a joint that may experience periodic movement or expansion. Also, materials must be compatible with each other. Certain kinds of sealants will actually dissolve plastic foam boards, while special kinds of tape are necessary to adhere to polyethylene.

Significant portions of most buildings are essentially air barriers to begin with, including gypsum or plaster ceilings, roof membranes and concrete slabs; all of which can be incorporated into the air barrier enclosure instead of attempting to create a new one from scratch. Air sealing work essentially consists of sealing the gaps between existing air-barrier materials to create a complete airtight enclosure.

\subsection{Developing an Air Sealing Work Scope}

Following the inspection, a thorough air sealing work scope should be developed, taking into account the existing building construction and knowledge of any planned additional work. Recommended details for addressing common leaks in multifamily attics and common air sealing materials are described in sections below. The attic/roof construction and any additional work being performed at the time will affect the decision of how to access the attic space to perform the air sealing work. Possible access could be from:

- Inside the attic/ceiling cavity

- The exterior roof surface

- Below with the interior ceiling removed

- Below through the finished ceiling.

Considering the number and types of air leaks, preferred methods of sealing, and questions of access, the following sections describe different approaches to an air sealing work scope. Care must be taken to ensure that any air sealing work does not have the potential to cause health risks.

From Inside the Attic/Ceiling Cavity:

If there is sufficient space to work inside the attic, air sealing work can proceed in much the same way that single-family attics are air sealed, with workers methodically removing insulation, inspecting for air leaks, and sealing any with an appropriate material. Working from inside the attic space is often the most cost effective and least disruptive way to perform air sealing work. In the example in Figure 13, the attic was accessed by cutting holes in the roof for workers to enter. After air sealing, the attic is insulated and a roof vent is installed as per code. 

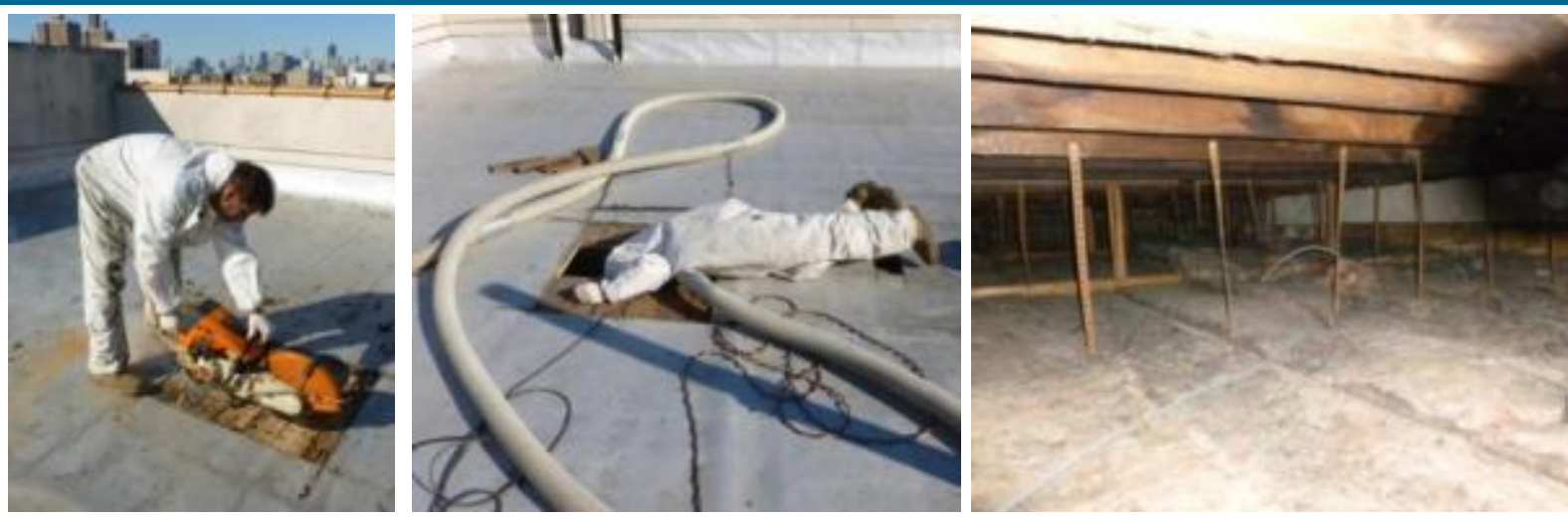

Figure 13. Accessing an attic through a cut-out in the roof (from left to right): A hole is cut with a saw; workers enter to perform air sealing; the available space in this attic affords good access.

Though cutting holes in the roof is the most direct way into the cavity, it may be possible to cut access holes either from an apartment up, or horizontally from a stairwell where it passes through the roof. Obviously, reducing the number of holes cut in the roof is preferable because it avoids the risk of water damage. It can also be difficult to coordinate the various stages of work including the removal of roof sections, inspection, cleaning, air sealing, and replacement and sealing or temporary waterproofing of an entire attic. Still, this approach is a common strategy to ensure that an attic is well protected from air leaks before insulation is installed.

From the Exterior Roof Surface:

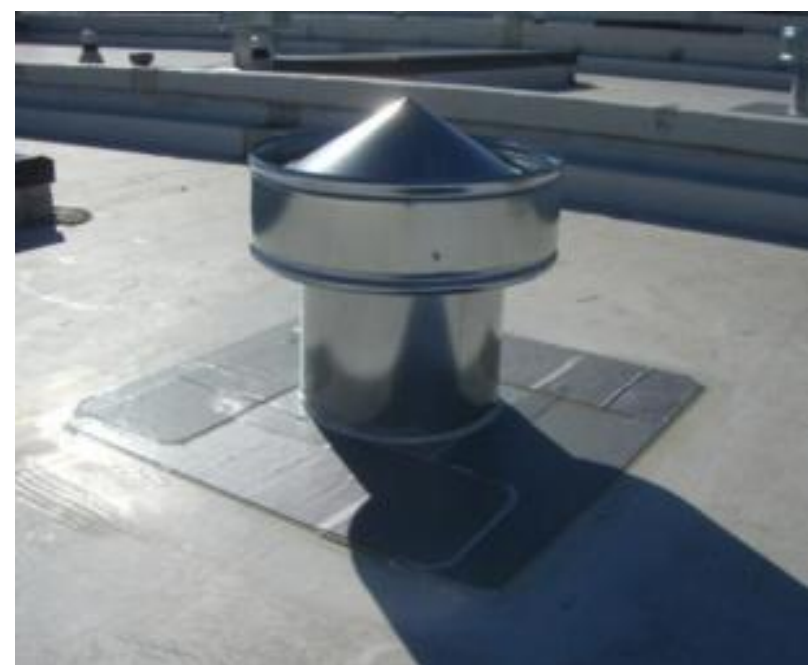

Figure 14. Roof vent installed with properly sealed butyl membrane

Many newer buildings are constructed without significant attics or cavities between conditioned space and the outdoors. Examples include concrete slab roofs or concrete plank roofs. In this case, it may be possible to address most air leaks right at the roof by sealing gaps at roof fan penetrations, roof/wall intersections, and other gaps in the roof air barrier.

From Below with Interior Ceiling Removed:

If the building is being substantially renovated, it may be possible to perform air sealing work from inside the apartments before the ceiling is reinstalled. This is essentially new-construction air sealing work. All service penetrations and walls are sealed to the greatest extent possible prior to the installation of ceiling drywall, which generally forms the primary air barrier in this situation. After drywall installation, all cutouts in the ceiling drywall are sealed from below using caulk or expanding foam. 

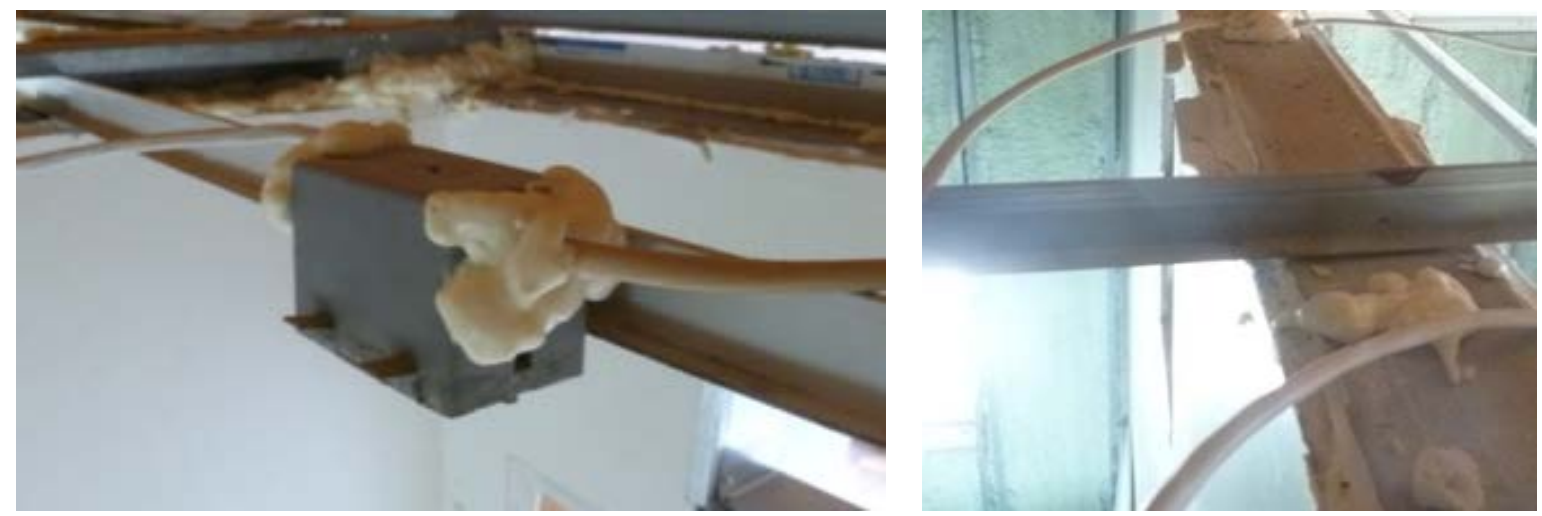

Figure 15. Air sealing junction boxes and top plate penetrations, before ceiling drywall is installed

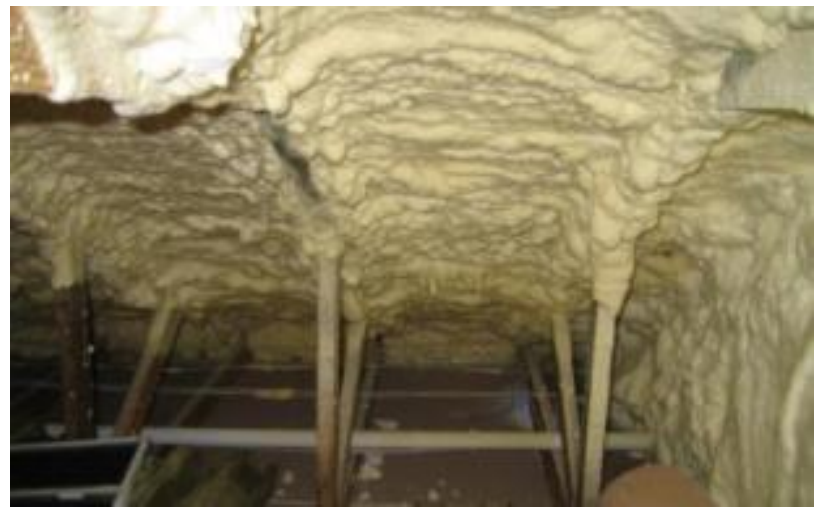

Figure 16. Polyurethane foam applied against underside of roof deck to convert to an unvented ceiling assembly

From Apartment/Living Space Through the Finished Ceiling:

For attics where it is not possible to work from the cavity to perform air sealing work it may be possible to air seal by cutting small holes into the ceiling and injecting low expansion polyurethane foam into the attic. This is much less disruptive than removing the entire ceiling, but is a much less common practice and has several possible complications. These include inability to easily monitor installed thickness and coverage and the need to use special formulations of spray foam. Some spray foam manufacturers do not support this method of installation.

Although this guide focuses on developing a comprehensive air sealing work scope and implementing it throughout a building, it should be noted that many air sealing tasks can be quickly performed from inside top-floor apartments, as a part of turnover or during a brief visit, and will yield small but real reductions in air leakage. Examples include caulking gaps at light fixtures, HVAC penetrations, and gaps in cabinets, closets, or soffits, etc. 


\section{Materials}

As noted earlier in this guide, a variety of materials are commonly used to perform air sealing work. All can contribute to creating an effective air barrier, if installed and detailed correctly. Quality workmanship is particularly important to successfully completing a quality air sealing project.

Common materials used for air sealing include:

- Spray polyurethane foams

- Barrier boards

- Caulk

- Drywall

- Plywood/OSB

- Wood

- Polyethylene sheeting

- Concrete

- Other non-porous materials with the ability to retain their strength over time.

Finding available air barrier materials may be easier than integrating them into a comprehensive system. Successful applications involve identifying the air barrier plane and maintaining its unbroken integrity throughout the attic.
Which material should you use?

When considering which materials are appropriate for a particular air-sealing challenge, consider the following:

- Is the material to be used in a fire-rated assembly? If so, ensure that the material used resists the spread of fire and the passage of smoke and other gases in compliance with code.

- Does it need to accommodate movement? If so, use a caulk or spray foam that is elastic.

- Is it bridging a large gap and does it need support? If so, consider using a solid blocking and then air sealing around the edges.

Ensure that the material you are considering is appropriate for the leak you have identified.

\subsection{Polyurethane Foams}

Polyurethane foams can provide both an air barrier and insulation. They can be applied over a variety of substrates and will expand to cover gaps and irregularities. Some spray foams must be professionally installed while others may be purchased as do-it-yourself kits from several manufacturers.

\section{Two-Part Spray Polyurethane Foams:}

Two-part spray polyurethane foams are created on-site by mixing two chemical components that react with each other and expand once they reach open air. This mixing occurs at the spray nozzle as the foam is applied. When the material hits the substrate it expands to many times its original size. Spray foam is both an excellent insulator and air sealing material. As insulation, it is fairly expensive, but as an air-sealing material it can be used in conjunction with cheaper insulation materials to achieve a combination of good air leakage reduction and insulation. There are two major types of two-part spray polyurethane foam: 
Open-Cell - Open-cell foam weighs about $1 / 2 \mathrm{lb} /$ cubic foot and typically has an R-value of 3.5/inch. In open-cell foam, the individual cells of polyurethane foam are open, making the foam softer and more porous.

Closed-Cell - Closed-cell foam weighs approximately $2 \mathrm{lb} /$ cubic foot. In closed-cell foams, the individual cells are closed and filled with blowing agent, which actually makes the product perform as a vapor barrier as well as an air barrier when installed to sufficient thickness (usually greater than 1.5 "). Closed cell spray foams are typically R- 6 per inch or greater. Closed-cell foams are much harder and are essentially waterproof.

Both types of two-part spray polyurethane foam are appropriate for sealing large or irregular gaps in the building envelope, although for very large gaps they may require some form of backing material. Polyurethane foam must be protected

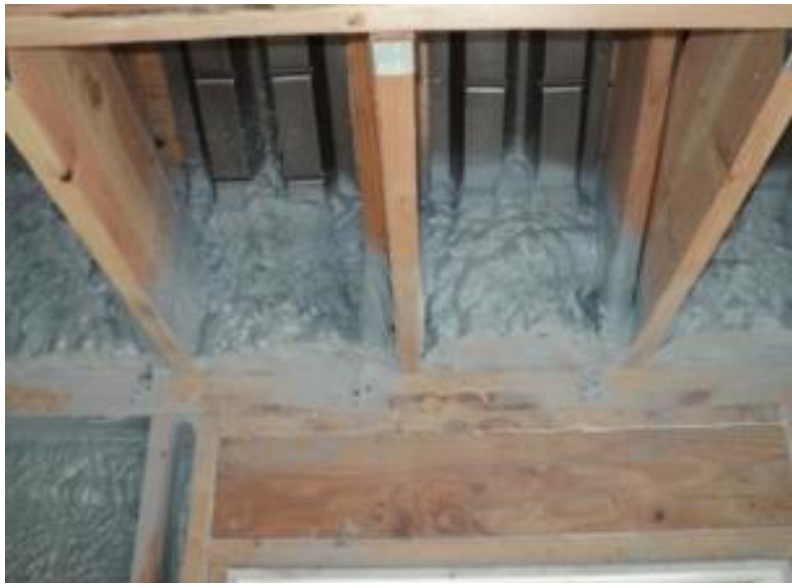

Figure 17. Closed-cell spray polyurethane foam quickly air seals and insulates this roof/wall/ceiling intersection from UV light which will break it down. Where it is used as insulation, codes may dictate that it be covered with a fire-resistant coating in some spaces. Manufacturer technical data sheets and ICC Evaluation Service reports for each particular foam will provide much of this information.

In addition to spray-in-place foams, there are also pour-in-place two-part foams available, which can be injected through small holes and which expand to fill a cavity.

\section{One-Part Polyurethane Foam:}

One-part polyurethane foam is available in disposable cans, as well as in professional systems that use a gun with replaceable cans of foam. This foam cures using moisture present in the air, and cures more slowly and expands less than two-part polyurethane foam. One-part polyurethane foam is appropriate for sealing gaps of from $1 / 4$ " to $2 "$, although larger gaps will require some form of backing material to support the foam while it cures. Polyurethane foam must be protected from UV light which will break it down.

Large openings can be sealed with a sheet of rigid air barrier material and a compatible sealant. The sheet material is cut to size and laid over the gap and any

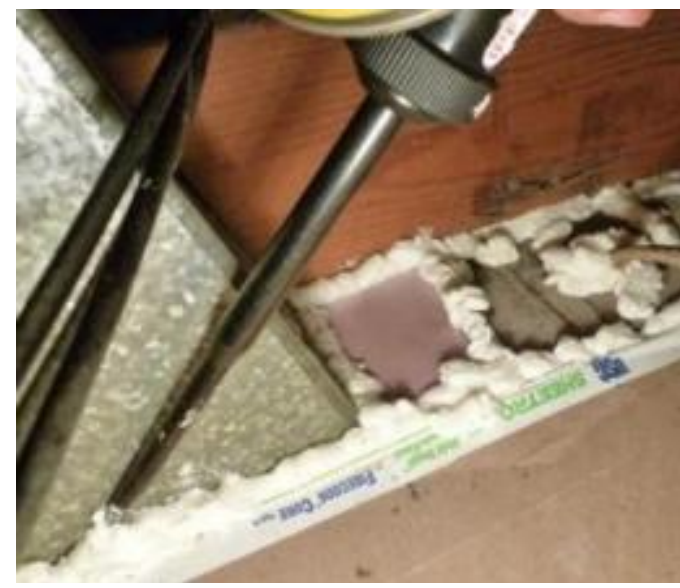

Figure 18. One-part foam effectively air seals these small irregular gaps at a duct penetration and top plate in an attic openings around the edges are sealed. If the gap is extremely large, it may be necessary to support it with some type of framing or reinforcing material such as wood or metal studs, as appropriate. Sheet materials suitable for air sealing use include plywood, extruded polystyrene 
(XPS) foam insulation, foil-faced polyisocyanurate insulation, and sheet metal, among many others.

One-part polyurethane foam is an excellent choice for sealing the gaps around barrier boards, but silicone or polyurethane caulk can also work well. It may be necessary to mechanically fasten the sheet materials to provide a durable installation.
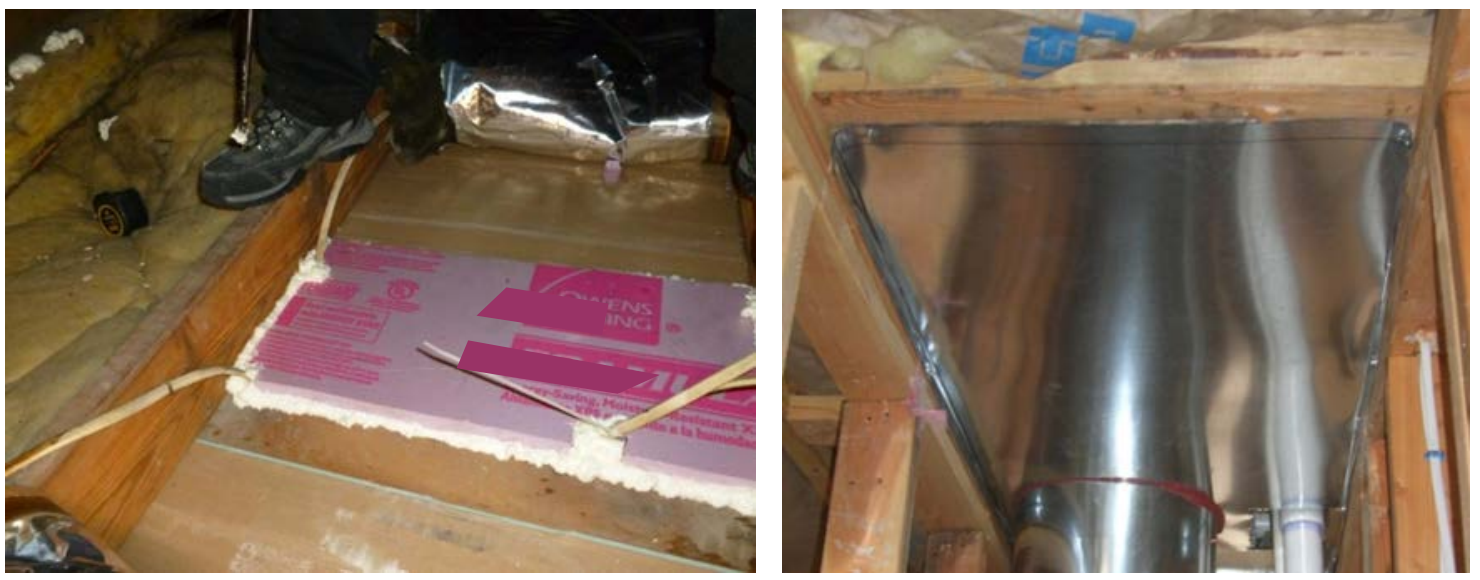

Figure 19. Gap sealed used one-part foam and rigid insulation board (left). Chimney flue being blocked with sheet metal and fire-rated caulk (right).

\subsection{Caulk}

Caulk is useful for sealing $1 / 2$ " or smaller openings. A variety of caulks are available, all of which are applied using a caulk gun. Caulk used for air sealing should be compatible with substrate materials. It also requires cleaner surfaces than polyurethane foam to adhere, so it is necessary to clean the surfaces before application.

A variety of caulks are available; in general descending order of price and effectiveness they include silicone, acrylic, and latex. There are also high temperature-resistant caulks that can be used to provide air sealing in fire-rated assemblies.

\subsection{Mastic}

Mastic is traditionally a duct-sealing material, but it has usefulness in sealing common building materials as well, as it is non-flammable and dries to a hard yet somewhat flexible finish. It is the obvious choice for sealing metal joints and ductwork, but it will also work to seal other building materials. It can be used for sealing high-temperature items such as insulation contact-rated lighting cans. It is applied using brushes, putty knives, or simply a gloved hand.

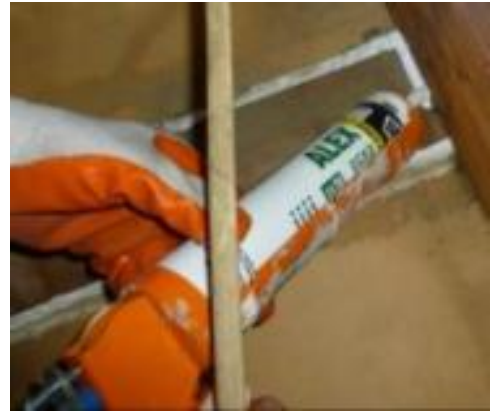

Figure 20. Caulk sealing small cracks

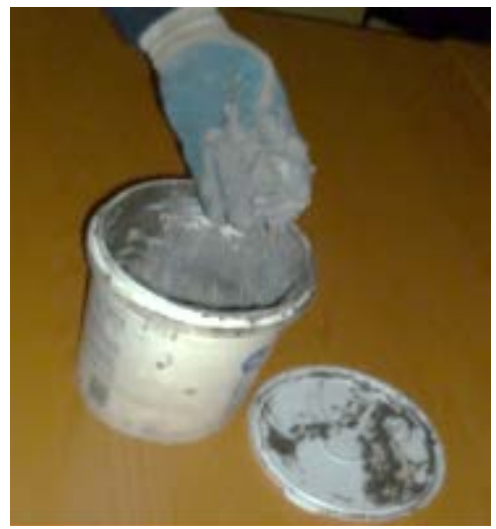

Figure 21. Mastic can be applied with a gloved hand 


\subsection{Non-Air Barrier Materials}

Some commonly used materials are not effective air barriers by themselves. These include:

Cellulose Insulation - Although it will certainly reduce the amount of air flowing through a cavity, dense-pack cellulose alone is not recommended as an air barrier because it may still allow a significant amount of air to pass through. Because insulating tends to reduce the temperature of outer surfaces in a building assembly, there is the possibility of condensation when air passes though the insulation and reaches the cold surface. Loose fill cellulose, commonly used for attic insulation, is less resistant to the passage of air than dense-packed cellulose.

Fiberglass Insulation - Fiberglass is commonly used to seal gaps by stuffing it into cavities, but fiberglass alone does not significantly reduce the passage of air. Dirty insulation from air passing through is a common sight in attics. Fiberglass can be used for air sealing work as a backing material for spray foams, or if it is placed in a plastic bag and then stuffed into a cavity.
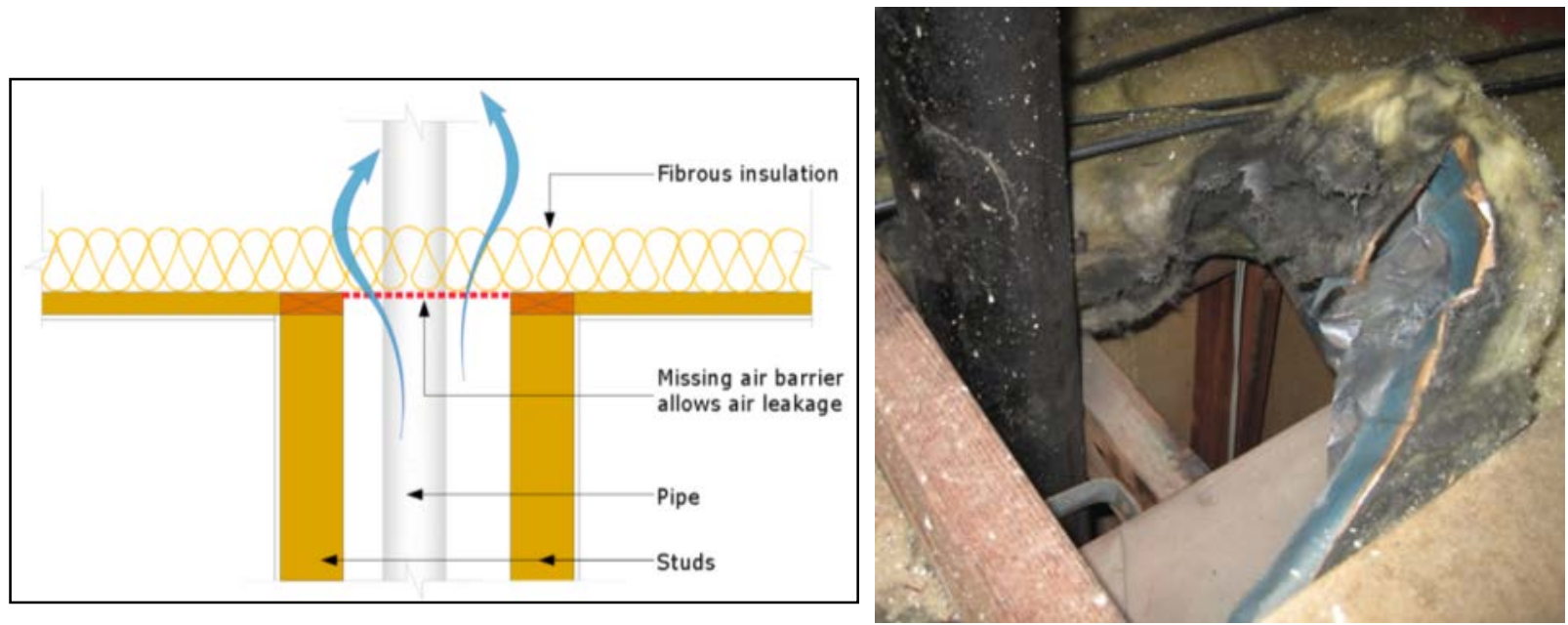

Figure 22. Fibrous insulation without an air barrier easily allows the passage of building air (left). Note dirty fiberglass surrounding this attic bypass, as air passes through the insulation but dirt gets trapped (right).

Rock/Mineral Wool Insulation - Rock/mineral wool insulation is commonly used in multifamily construction due to its innate fire-resistant qualities. Still, like cellulose and fiberglass, rock/mineral wool insulation is not an air barrier. 


\section{Measure Implementation Details}

Since every building is different, it is necessary to identify an air sealing package that addresses its unique challenges. The following measures address specific areas that commonly need air sealing in multifamily buildings. Where appropriate, a variety of different solutions are described, including for gut retrofit projects where the ceiling is removed. Once the location of the air barrier has been selected, the following measures can be used as needed and appropriate to complete the attic air barrier assembly.

The diagram below shows the locations of several common leaks in multifamily buildings. The following pages detail strategies for sealing each of them.

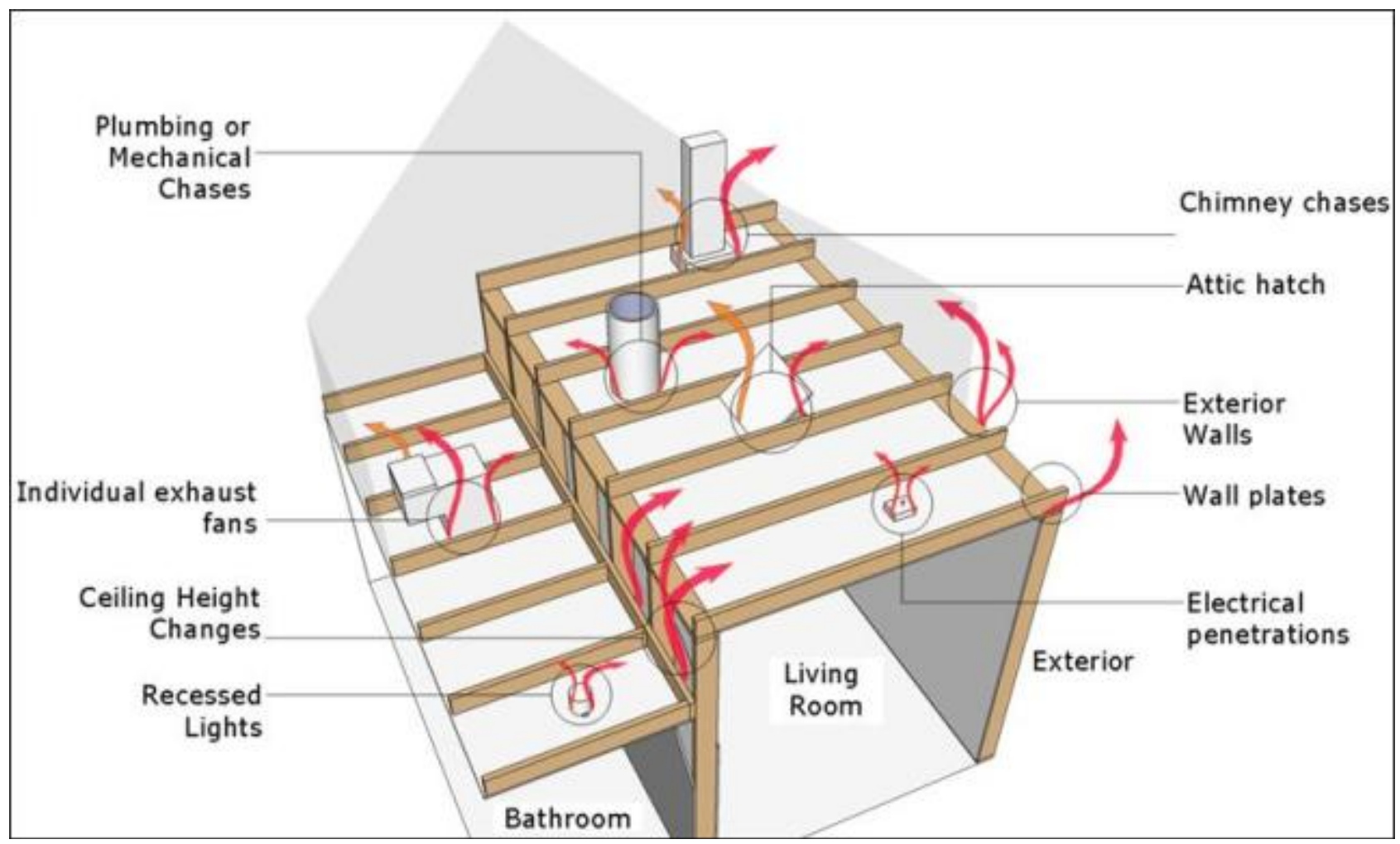

Figure 23. Common leakage sites in a multifamily building attic

\subsection{Electrical Penetrations}

Gaps around wires or electrical boxes are usually small and can be easily addressed with caulk or one-part polyurethane foam. Holes in the box itself should be sealed as well as any gaps around them. Care should be taken ensure that non-fire rated foams and caulks are not applied in a manner that results in them overflowing inside the electric box as this can be a possible code violation and fire hazard.

For a gut-rehab project, sealing of electrical penetrations may be accomplished before drywall is installed. Tops of electrical boxes can be sealed beforehand, as well as penetrations through top plates and partitions. In any place where electrical wires pass through the ceiling plane, the penetration should be sealed with caulk or foam before drywall installation. 

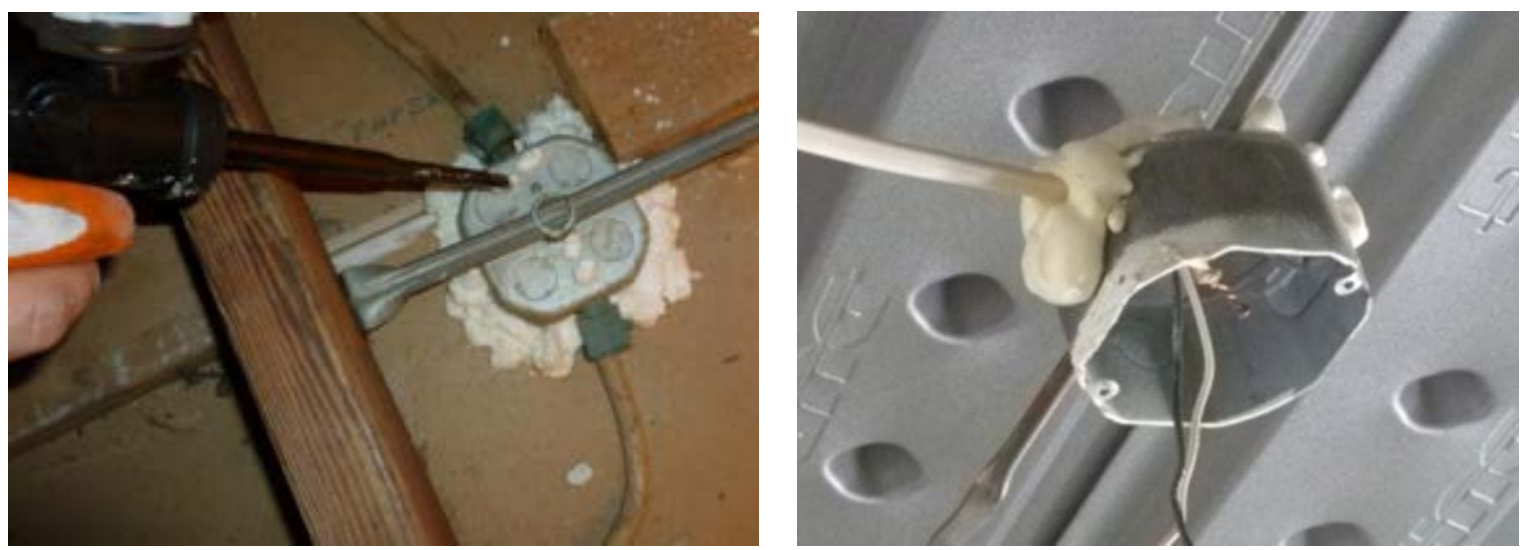

Figure 24. Sealing a common electrical penetration (left). Electrical box sealed before drywall installation (right).

\subsection{Partition Walls and Top Plates}

Partition wall framing frequently interrupts the air barrier at the ceiling plane, creating numerous small leaks that must be sealed. Gaps are generally narrow and can be sealed with one-part foam or caulk.
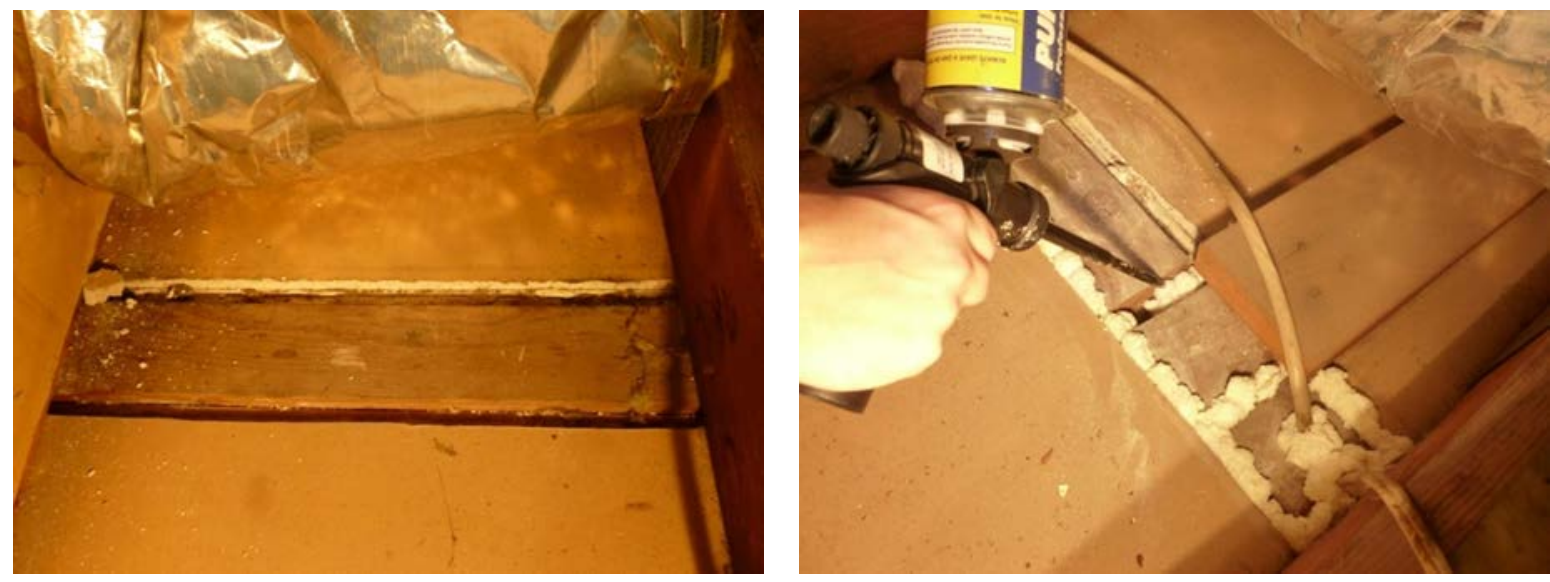

Figure 25. Common partition wall gap (left). Expanding foam quickly seals gaps at top plates (right).

\subsection{Plumbing or Mechanical Chases}

Chases for building services are often completely open at the top, creating a large opening for conditioned air to escape. Sealing these chases should be one of the highest priorities when air sealing an attic. Generally barrier boards or some rigid backing combined with expanding foam are necessary to seal around the openings. In taller buildings, the stack pressure working against any air sealing can be significant. Any barrier boards used should be rigid and securely fastened to the building structure in order to provide a durable installation. 


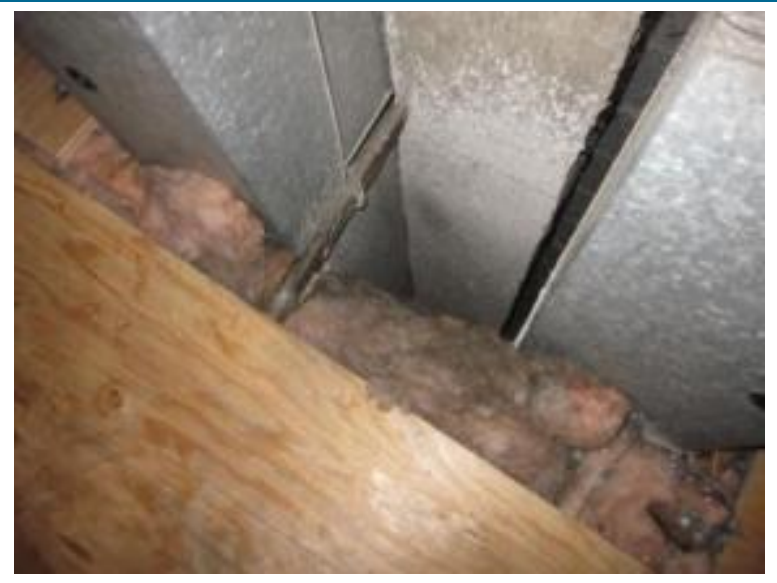

Figure 26. Mechanical chase in attic of a mid-rise apartment building

In order to seal these large bypasses, you must measure the gap, and cut the barrier board to size accounting for any notches for wires, pipes or other obstructions. Attach the board to the framing using nails or screws, and then seal the entire perimeter of the board using expanding foam or caulk.

\subsection{Exterior Walls}

Many older masonry buildings have exterior walls in which plaster or drywall is applied over furring on the brick. There may be a gap where the furred exterior wall joins the attic. Depending on size, the gap should be sealed using foam, caulk, or a combination of barrier boards and foam. For new construction and gut renovations, this gap can also be easily sealed from below. As discussed before, warm, humid air (from the living space) enters the attic during the winter through leaks such as this and comes in contact with wood joists and decking. Any insulation at the ceiling plane will not stop air movement but will make wood joists and decking colder during the winter. This increases attic relative humidity and makes condensation possible.
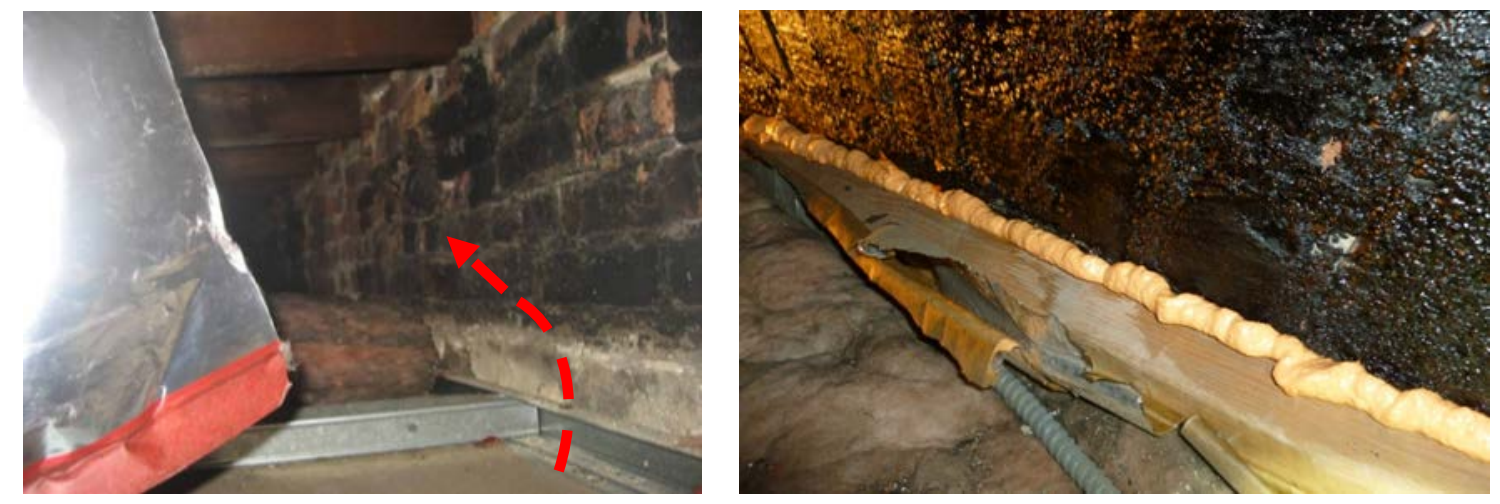

Figure 27. Typical leakage location at exterior wall and arrow showing path of air movement (left). Gap sealed using one-part expanding foam (right).

This air leakage path exists in many buildings in which there is no attic access. If an extensive renovation is not planned, selective cut outs of the ceiling drywall at the perimeter of the top unit(s) to gain access to this gap can be an effective method to rectify this bypass. 


\subsection{Dropped Soffits}

Dropped soffits for cabinets or duct work are often open at the top, creating large openings connecting partition wall framing to the attic. These gaps are often easiest to seal using barrier boards. It may be necessary to add framing to provide adequate support for board materials used when sealing large gaps. Make sure to use materials that are able to withstand some weight if insulation is to be applied on top of them. A step-bystep guide to sealing a soffit and other large chase is shown to the right.

1. The bypass is measured.

2. The board is measured, and provisions for necessary penetrations are included.

3. The board is cut to size with cutouts for penetrations.

4. The board is entirely sealed around with spray foam or caulk, as appropriate.

For gut renovations, it is ideal to plan ahead to provide a continuous air barrier and avoid the dropped soffit bypass entirely. In the image below, a drywall box is installed in the corner before the soffit framing is installed. Then, services are run in the soffit, framing is installed, and the soffit is finished. The finished product is much more airtight than a traditionally completed soffit.

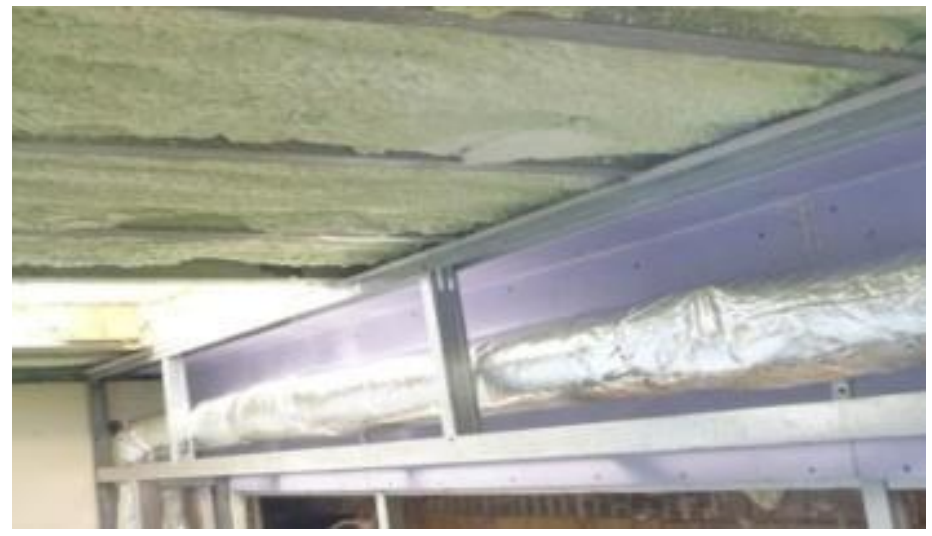

Figure 29. Soffit with continuous drywall at ceiling in a gut-rehab project
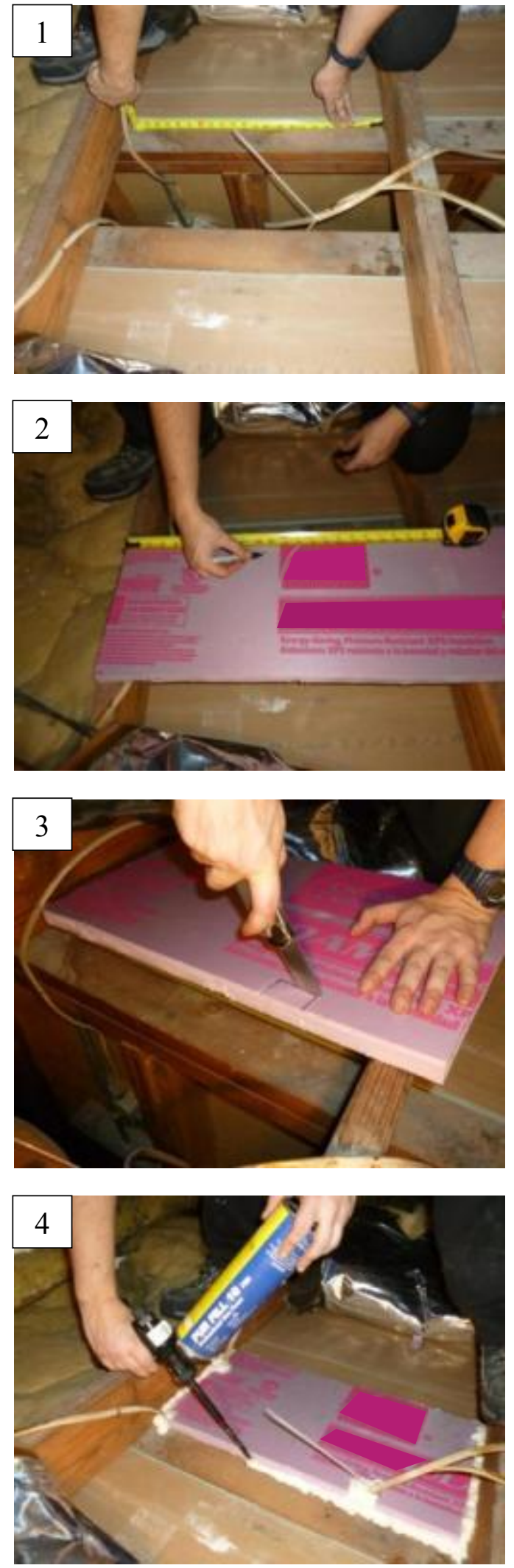

Figure 28. Step-by-step sequence for blocking an open soffit from attic side. 


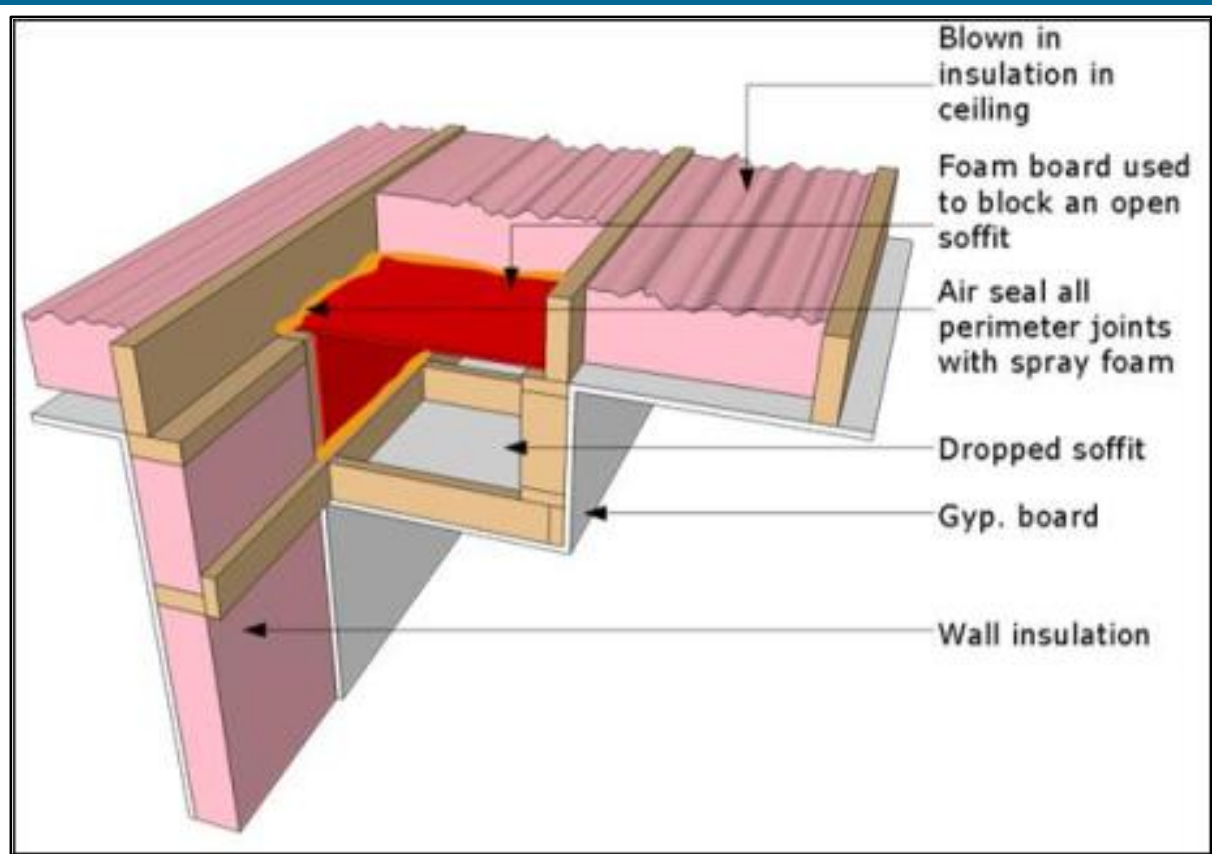

Figure 30. Recommended location of air barriers (in red) of a well-sealed soffit

\subsection{Wall Transition}

Ceiling heights may vary within an apartment. One example is when dropped ceilings exist in kitchens and bathrooms to accommodate services or provide architectural enhancement. Where the walls and the ceilings meet, stud cavities may create numerous large bypasses into the attic space. These gaps must be sealed by closing off the stud cavity with a rigid barrier board and spray foam sealant. Alternatively, unfaced fiberglass insulation can be stuffed into plastic bags and packed tightly into the cavity. The plastic bag forms an air barrier, and it is sealed around the edge with spray foam. See Figure 31 and Figure 32 for a depiction of the problem and the solution.
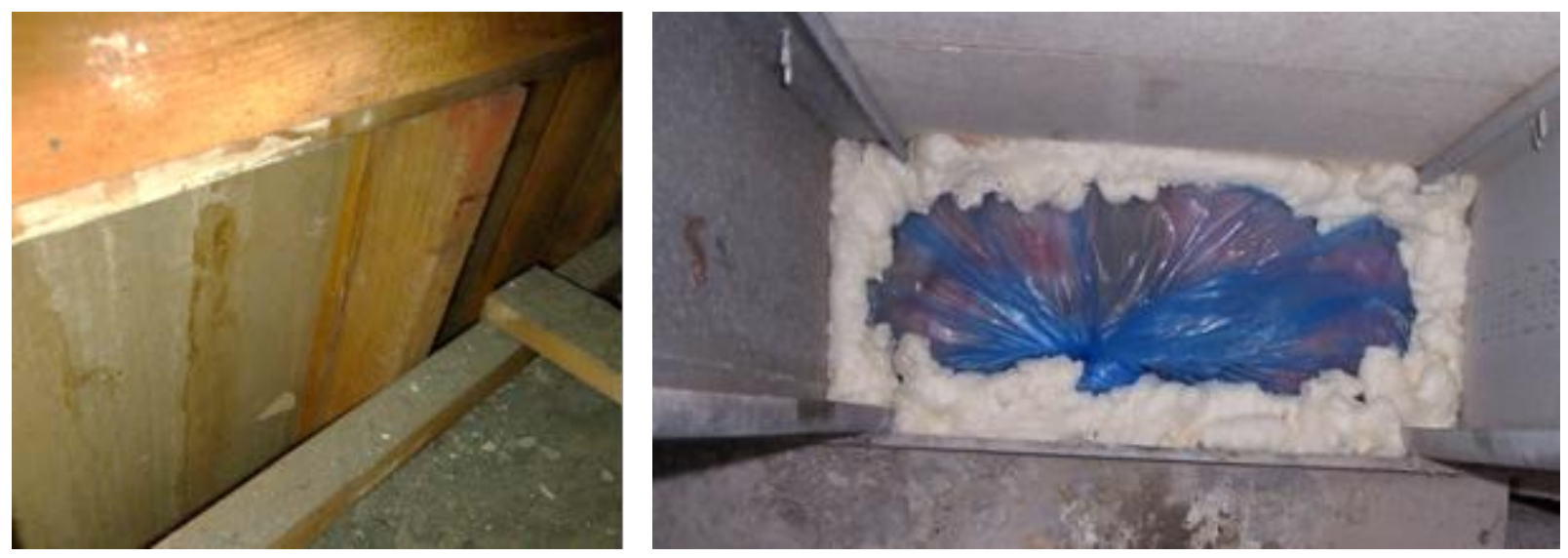

Figure 31. Open stud cavity (left) and stud cavity sealed using bagged insulation and spray foam (above). 


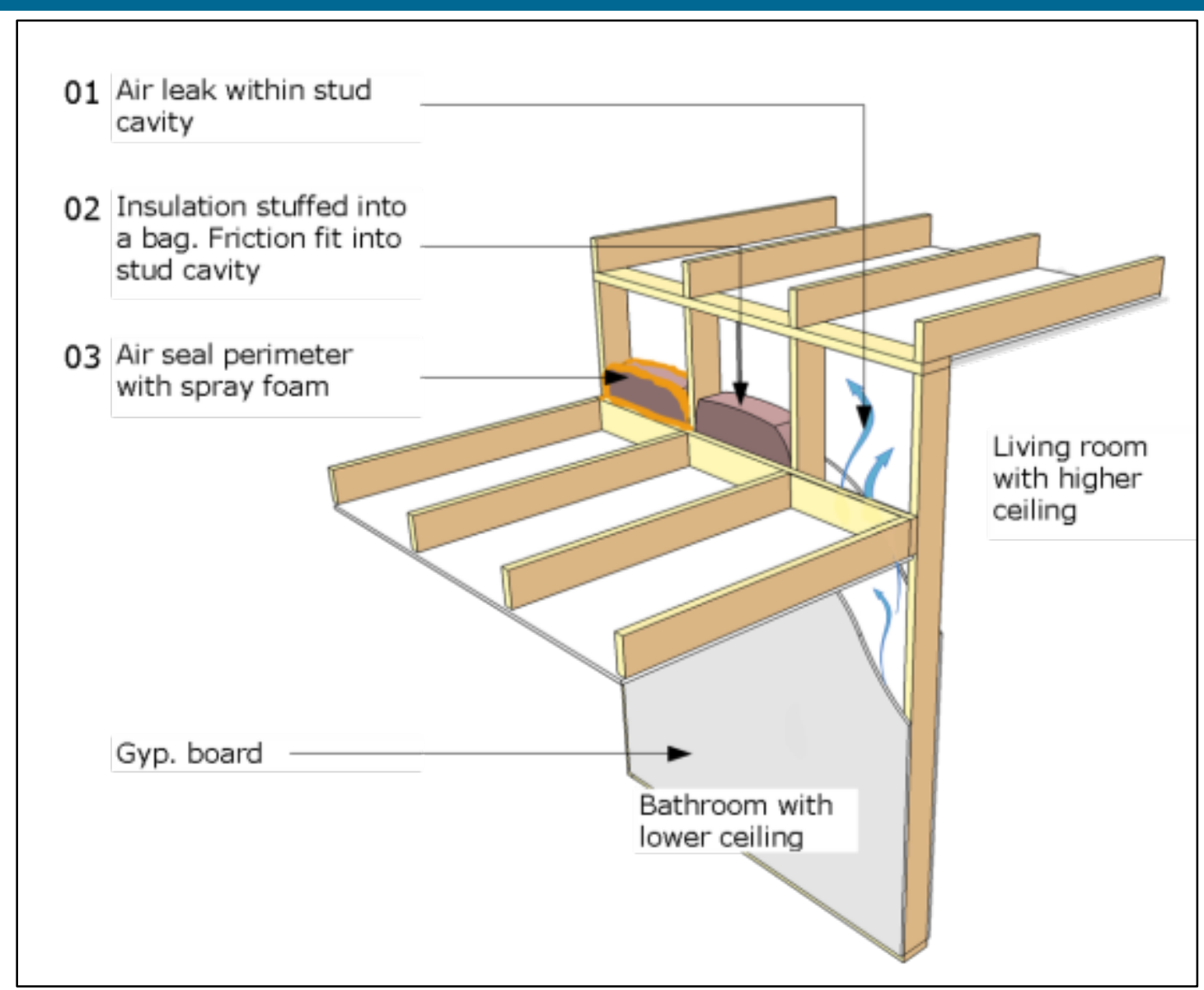

Figure 32. Air leakage at ceiling height changes, and how to air seal the cavities using bags stuffed with fiberglass.

\subsection{Recessed Lights}

Recessed can lights are often very leaky, but they can be difficult to air seal correctly. If they are present, it is important to determine if they are rated for insulation contact ("IC-rated"). If so, they can be directly sealed with mastic, spray foam, or other sealant, and insulation can be placed directly over them. If they are not IC-rated, a box enclosure may be made from fire-resistant material to keep insulation at a distance, so that the fixture does not overheat. Appropriate materials for this enclosure include fiberglass duct board or drywall. This can then be air sealed with caulk or mastic and covered with insulation. It is important to allow enough clearance (about 3" to each side) inside the box for heat to dissipate. Alternatively, there are several manufacturers that sell pre-made recessed light covers. Either way, the box should then be well sealed to the ceiling.

Air-tight IC-rated recessed light fixtures are available and have undergone air leakage testing and are specially labeled (see Figure 33). They can be used to minimize air sealing work for new construction and gut renovations. It is still recommended that similar air sealing be performed on this "air-tight" IC-rated can to seal all wiring penetrations into the can itself and any openings or punch-outs in the can body. 

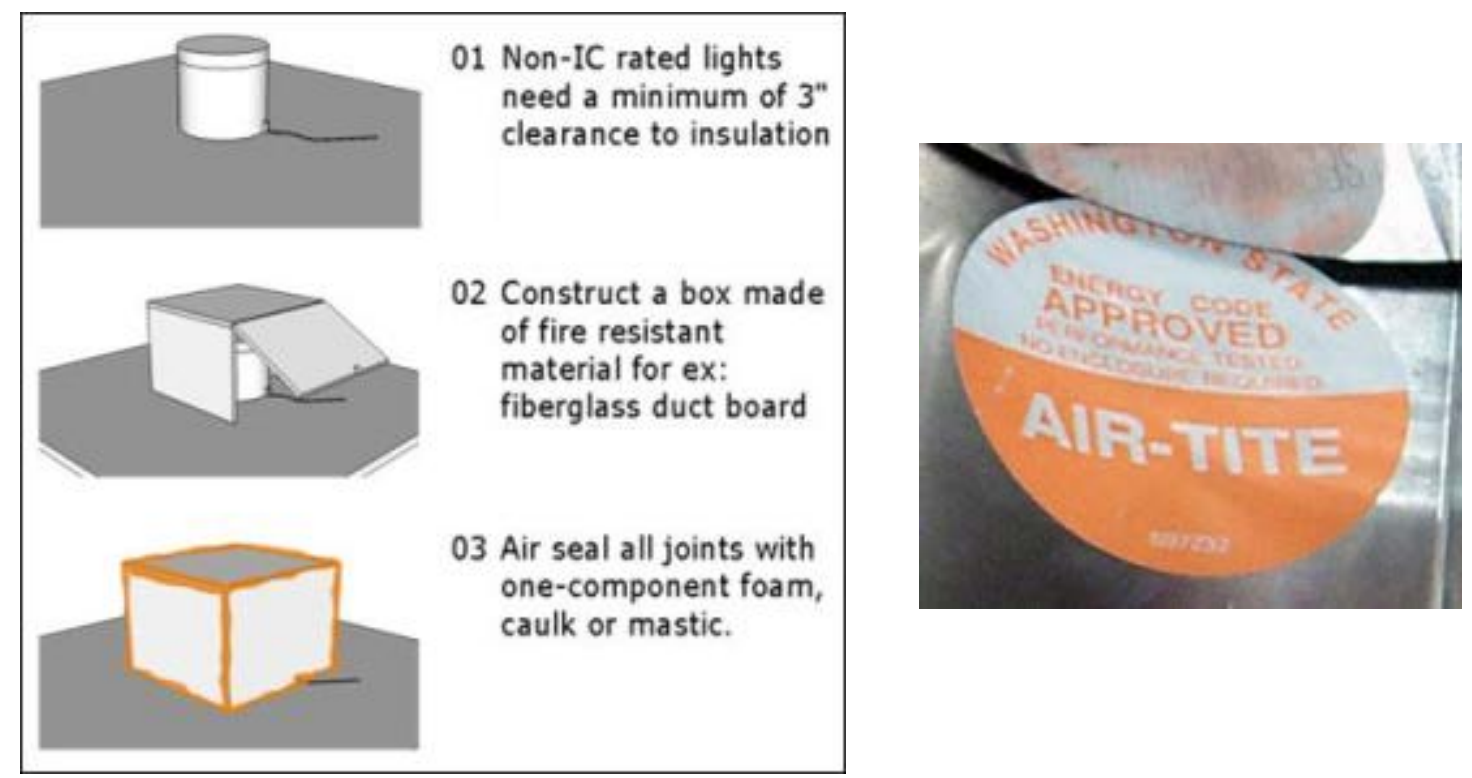

Figure 33. Procedure to air seal non-IC rated lights (left). Air tight recessed light label (BECRC) (right).

\subsection{Chimney Chases}

There is often a significant gap between a chimney or heating system flue and neighboring materials, resulting in significant leakage. These gaps can often be easily sealed, but chimneys require additional consideration due to requirements for clearance to combustible materials. Generally 2" clearance on all sides is required, although this may vary and the relevant local codes should be consulted before performing work on chimneys.

Sheet metal is often used to seal around a chimney, essentially as a barrier board, with any remaining gaps sealed with an appropriate high-temperature caulk. If blown in insulation is to be added to the attic following air sealing it will be necessary to add a vertical dam to maintain the required clearance from the chimney to above the depth of the insulation. Alternatively, rock wool insulation is rated for this application. Photos and graphics below explain the process.
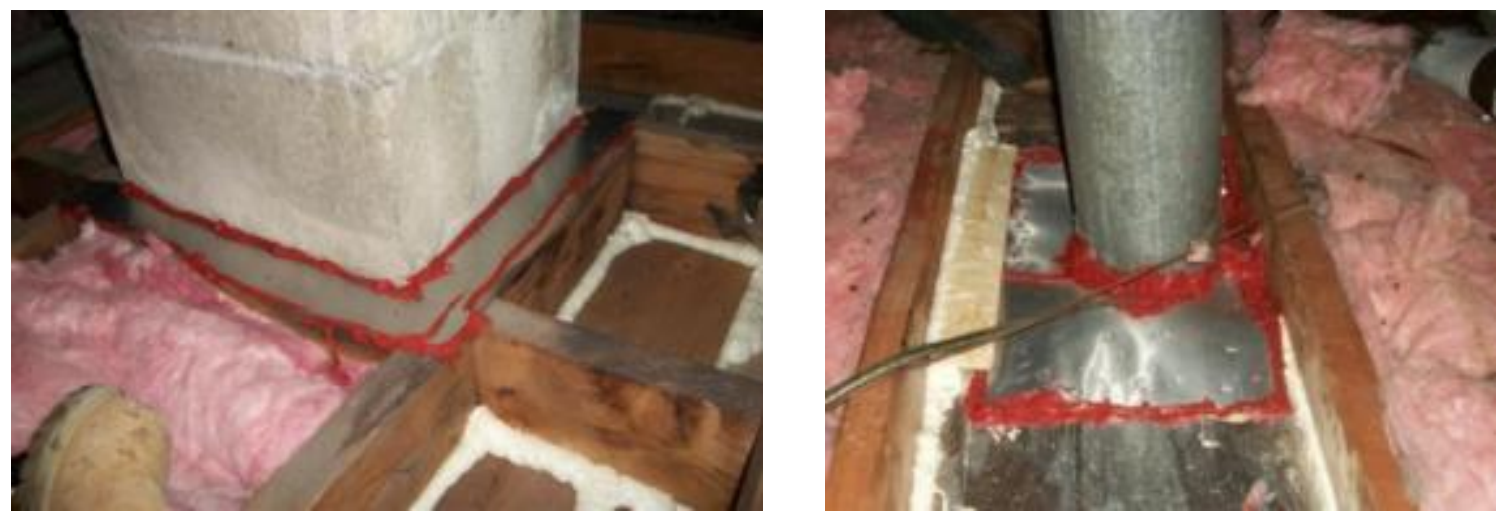

Figure 34. Sheetmetal blocking around chimneys Insulation dams still need to be installed. (Photos courtesy of Next Step Living, printed with permission) 


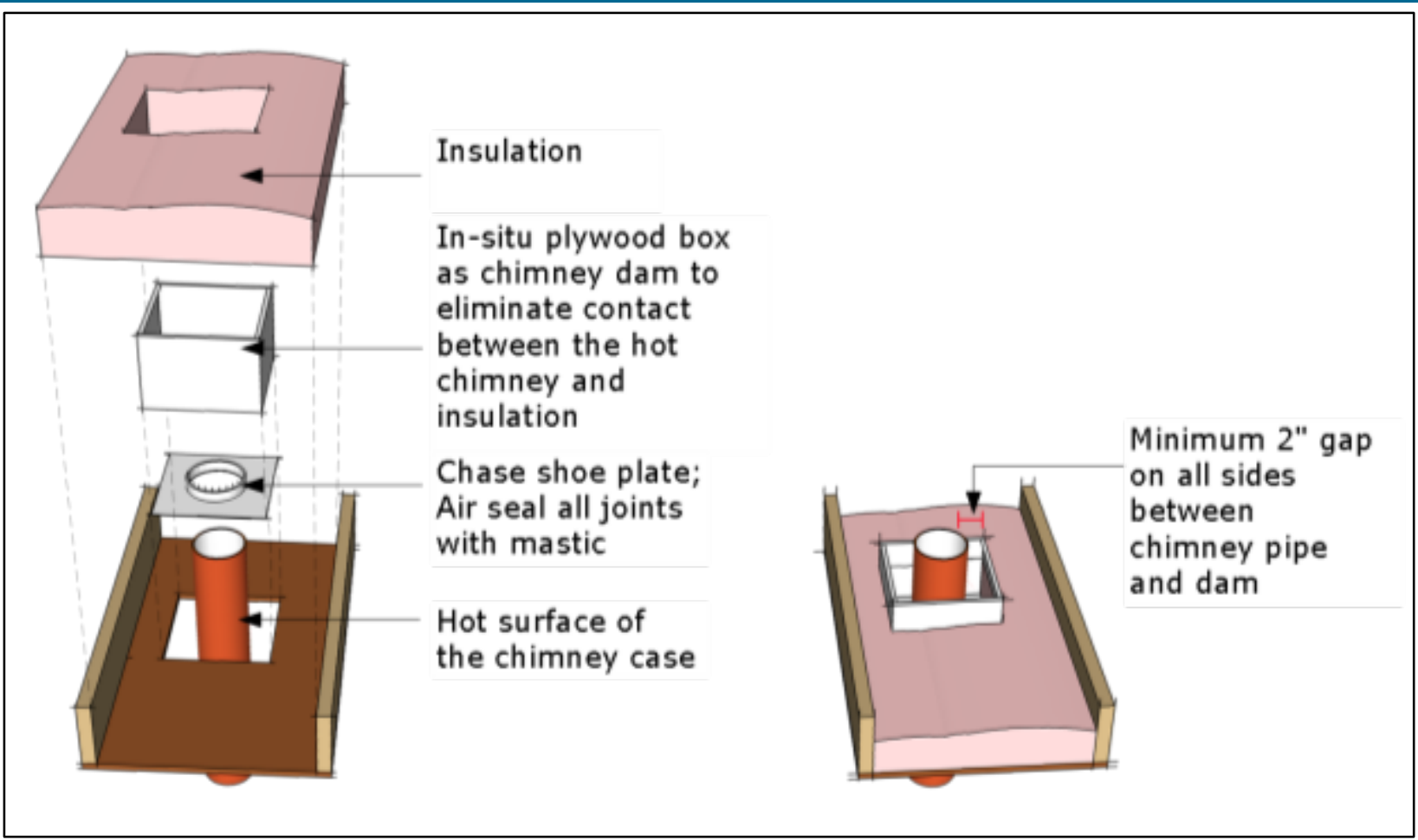

Figure 35. Necessary components for air sealing and insulating at chimney

\subsection{Gaps at Duct Penetrations}

Ductwork passing through attic spaces can be a source of significant air leakage. The chase through which the duct passes is often open between floors and may run the entire height of the building before ending in the attic. The ductwork itself may be leaky as well, so depending on the whether the duct is for supply or exhaust it may be pushing air into the attic or drawing it out.

Large roof fans are typically installed on a curb that sits on the roof deck. The curb covers a hole cut in the deck which generally (but not always) has a duct installed in it. If the connection between the fan and the duct work is not airtight, the fan can pull air from the attic space rather than from the duct work.

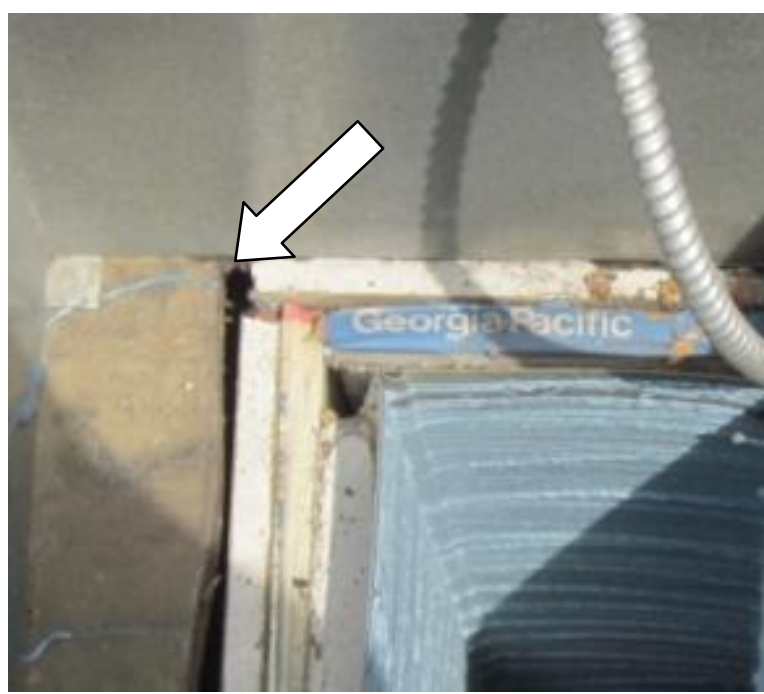

Figure 36. Unsealed gap at duct work penetration, viewed from roof

It may be easier to seal gaps at the roof curb by removing the fan rather than working from the attic. If working from the attic, check carefully for any gaps between the ductwork and the roof penetration. 

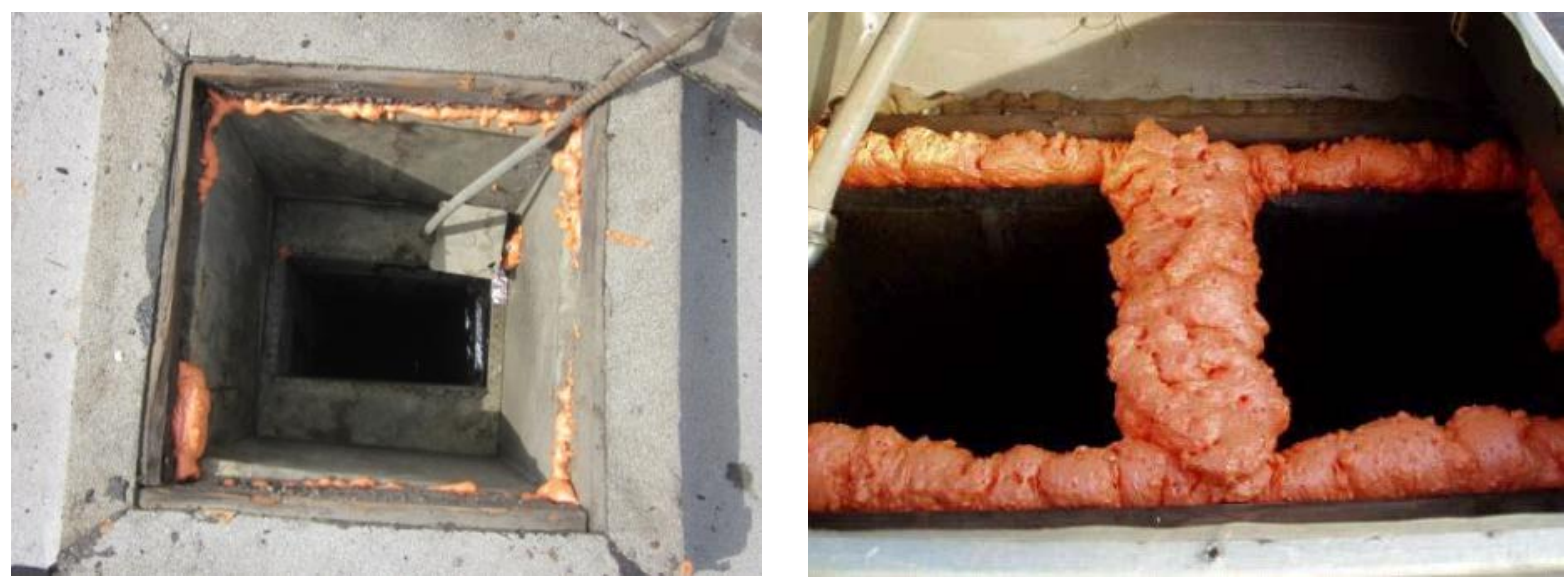

Figure 37. Gaps at roof curb sealed from rooftop

If individual bathroom or kitchen fans are installed, the cutout in the ceiling should be sealed to the fan housing around the perimeter, either from inside the apartment with the grille removed, and/or from the attic. Acceptable materials include caulk, mastic, or foam.

It is not uncommon to find fans that eject exhaust into attic space instead of being run to the outdoors. As discussed before, this is potentially very damaging to the roof structure. All exhaust fans should be ducted to the outdoors, and ductwork should be airtight.
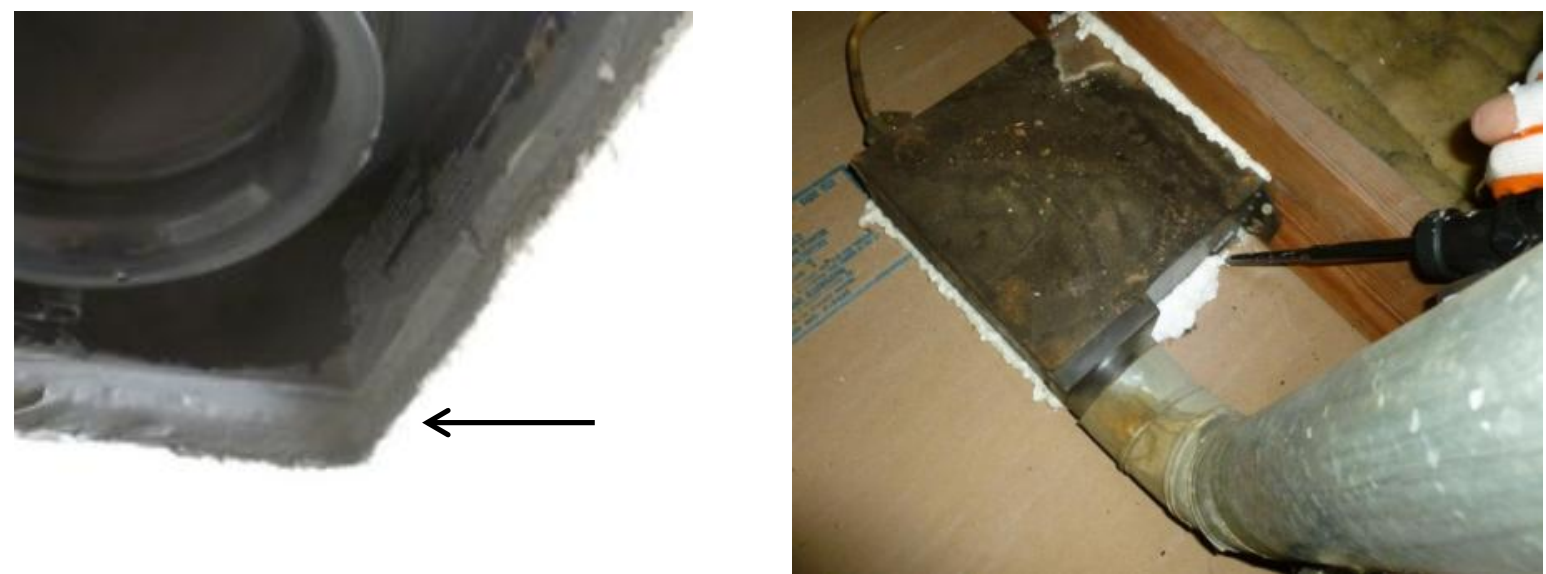

Figure 38. Caulked gap at apartment side of fan penetration (left). Sealing bath fan penetration with foam from attic side (right).

While addressing issues of air sealing, and the attic and ducts are accessible, make sure to take this opportunity to seal the ductwork as well. Otherwise you may be diminishing your attic air sealing efforts. Though not specific to multifamily, a useful resource is the Department of Energy's "Measure Guideline: Sealing and Insulating Ducts in Existing Homes", which is available here.

\subsection{Fire-Rated Assemblies}

Many multifamily buildings incorporate fire-rated demising walls that pass through the attic space, and there may be other types of fire-rated assemblies as well. If these walls need air sealing, it is necessary to use appropriate materials in order to maintain the fire rating of the 
assembly. It is important to note that the presence of gaps and bypasses in a fire-rated wall can compromise the performance of the wall if there is a fire. Some fire-rated walls separate only two unconditioned attics, so air sealing them may not be necessary from an energy perspective. Still, there are instances where fire-rated walls do separate living space from unconditioned space in another apartment, and the materials used to seal these walls must not compromise their fire rating.
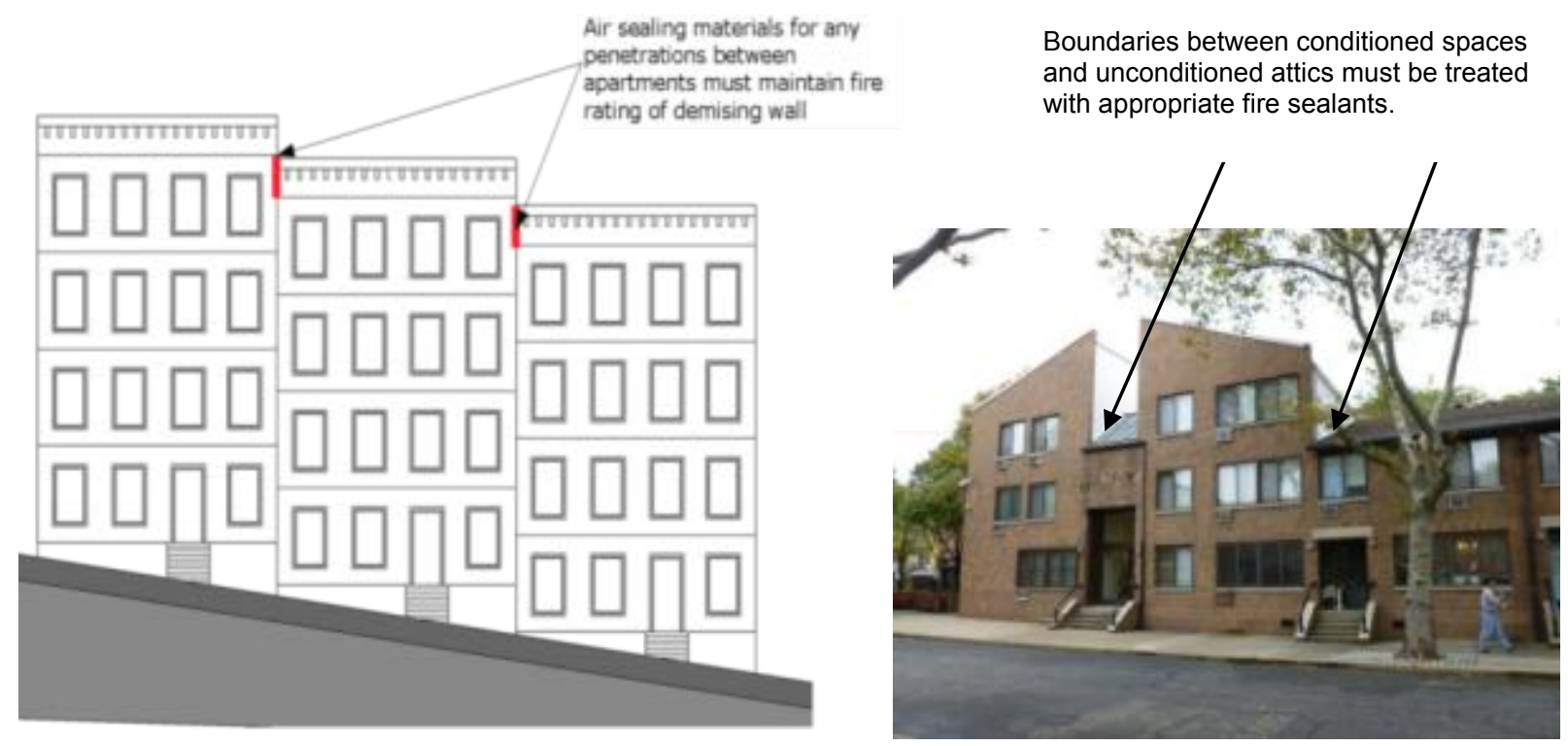

Figure 39. It is necessary to maintain fire ratings between conditioned spaces and unconditioned attics of neighboring apartments

Gaps in fire-rated walls are sealed in the same fashion as other walls, but it is necessary to use fire-resistant materials to do so. Many appropriate materials are available, including intumescent caulks, high temperature caulks, and high temperature one-component foam. If larger gaps have to be sealed, drywall or sheet metal can be used for the gaps in conjunction with sealant materials.
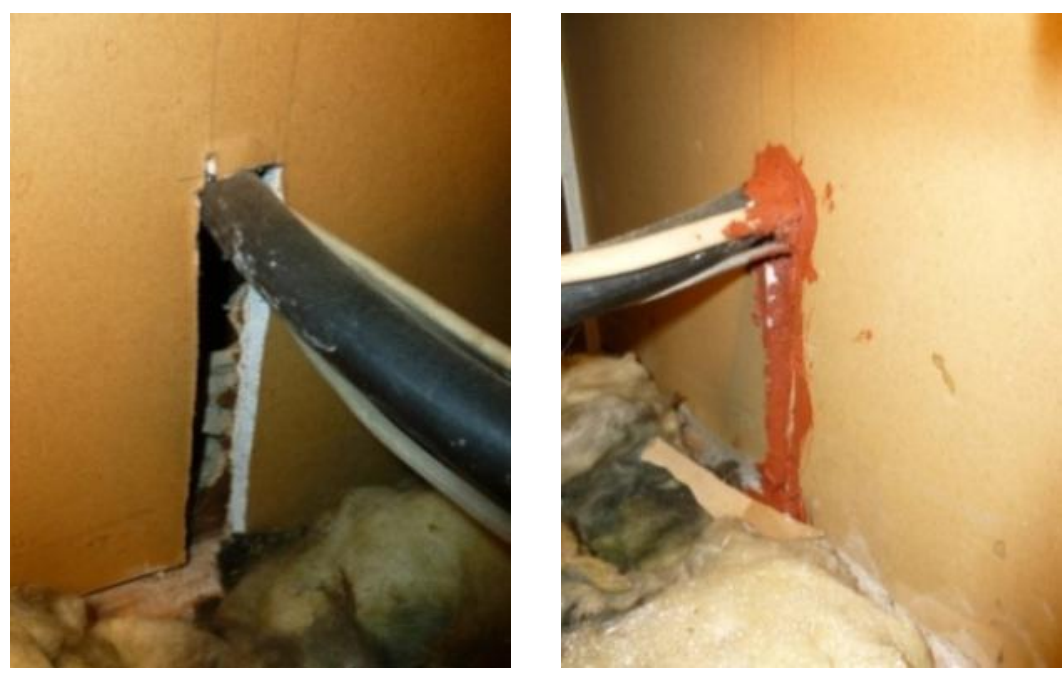

Figure 40. Process of sealing a hole in a fire-rated assembly between apartments 


\section{Special Considerations for Fire}

All modern building codes have rules meant to make buildings safer in the event of a fire. "Fire-rated assemblies" are those that are designed and tested to withstand high temperatures for a specified length of time without losing integrity. One thing to remember is that there is no such thing as a "fire-rated material," and the presence of fire-resistant materials does not make an assembly fire-rated. Materials must be installed properly and as a complete system that conforms to building codes.

While many common fire-resistant building materials are used as air barriers, some airsealing materials are combustible. A specific example is spray polyurethane foam, which is an excellent product to air seal and insulate attics, but which must be covered with an ignition barrier in some situations. Codes vary as to requirements, so it is best to check with officials before undertaking large projects with these types of materials.

\subsection{Access Panels and Hatches}

Access panels and hatchways leading into the attic or roof cavity can be a major source of leakage if not properly sealed.

Door-style access panels with hinges that open down should be fitted with peel-and-stick closed-cell weather-stripping where the door meets the frame on all four sides. It is important to choose the correct thickness of weather-stripping to provide a good seal while allowing the door to close tightly.

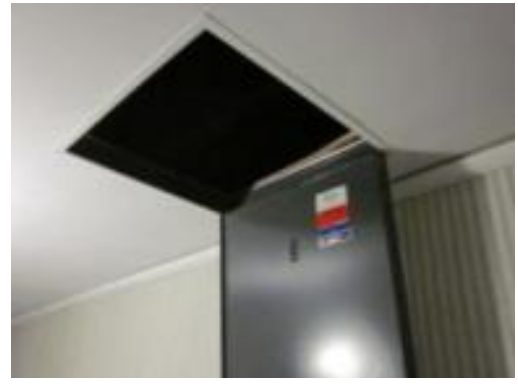

Figure 41. Attic access hatch

Lift-out hatches without hinges often need a continuous frame installed around the perimeter of the hatch opening to aid in making a durable seal. Peel-and-stick weather-stripping can then be applied to the upper face of this frame where the hatch rests. Latches, such as hooks and eyes, can be installed to provide compression to the weather-stripping for a good seal.
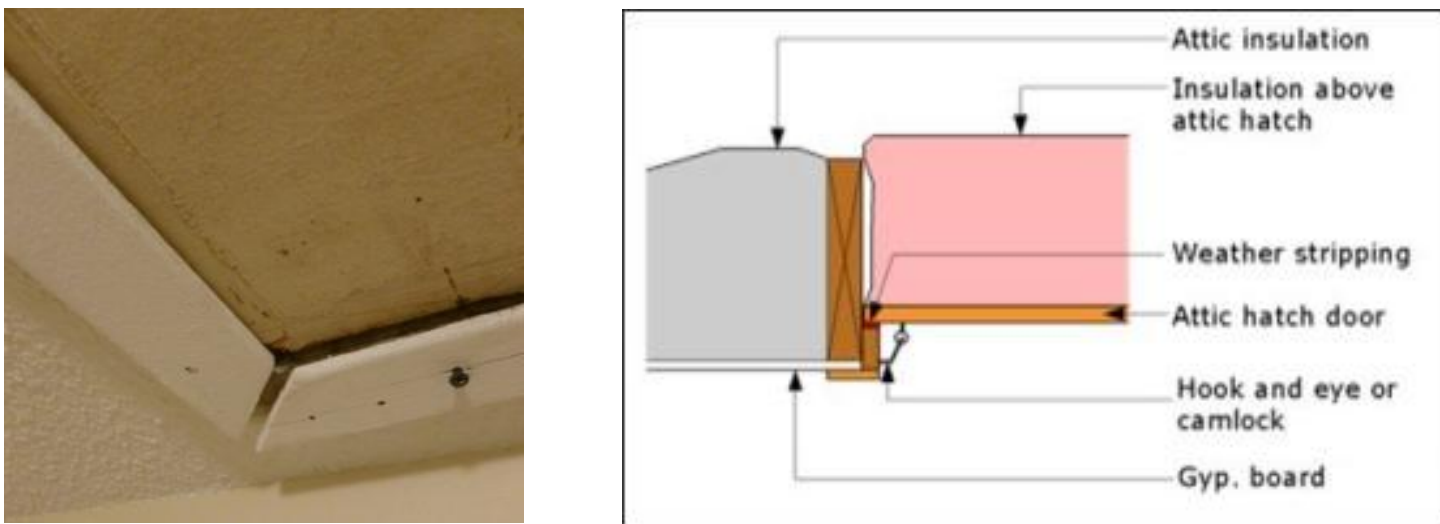

Figure 42. Air sealing a lift-out attic hatch 


\section{Projects/Case Studies}

\subsection{Low-Rise Town Home}

Townhouse attics are often similar to single-family residential attics, but in some cases, numerous attached units can have a shared attic.
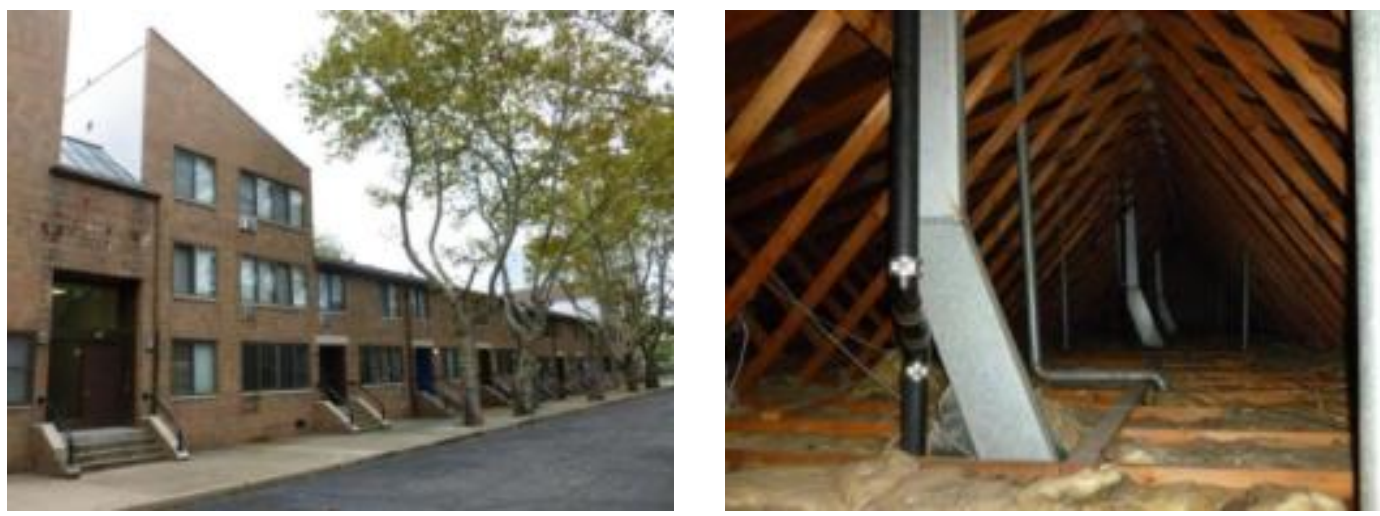

Figure 43. Shared attic for attached townhouses

This building complex was built in the 1960s, consisting of town houses that share demising walls. Roofs are pitched and framed with open-web trusses and the roof cavity is vented. The ceiling is currently insulated with fiberglass batts laid between ceiling framing members. Air sealing work in this type of multifamily building shares many similarities with that of singlefamily homes.

Identified Challenges:

No air sealing work in the attic has been done yet. Each unit has the similar penetrations in approximately the same configuration:

1. Plumbing chases

2. Dropped soffits

3. Exhaust fans

4. Electrical penetrations

5. Attic hatches

How to Retrofit:

This is a straightforward air sealing project with challenges similar to those found in single-family homes. There is sufficient space for workers to perform all necessary work. All gaps should be sealed with spray foam and barrier boards as appropriate. Trim should be added to the attic hatches as needed to provide support for weatherstripping, and latches provided to hold hatches tight against the weather-stripping.

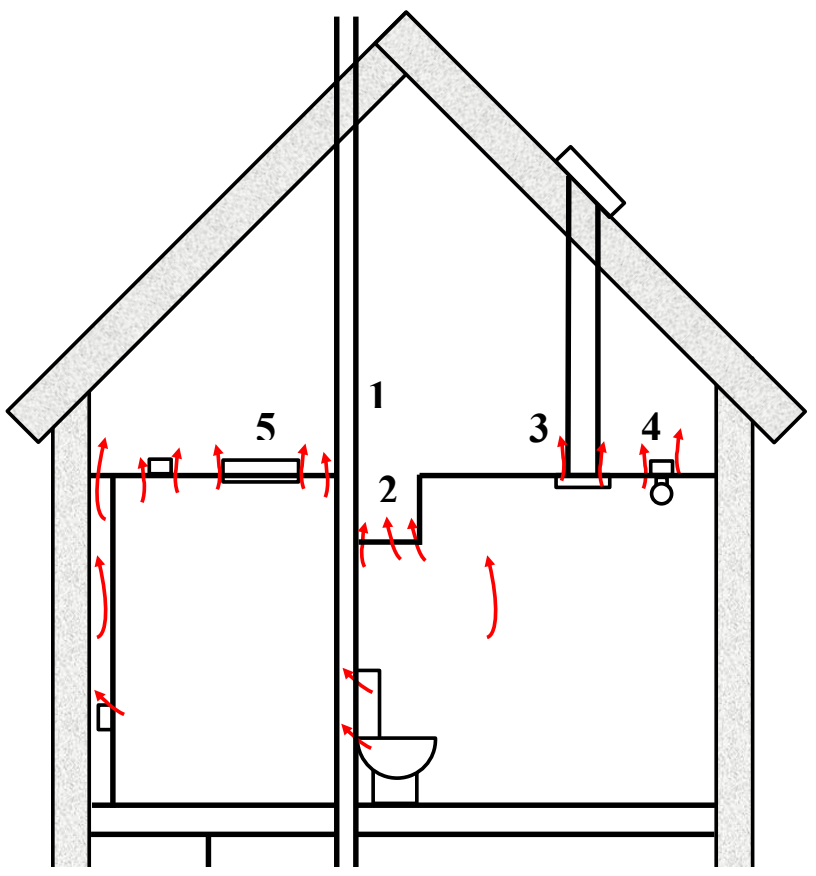




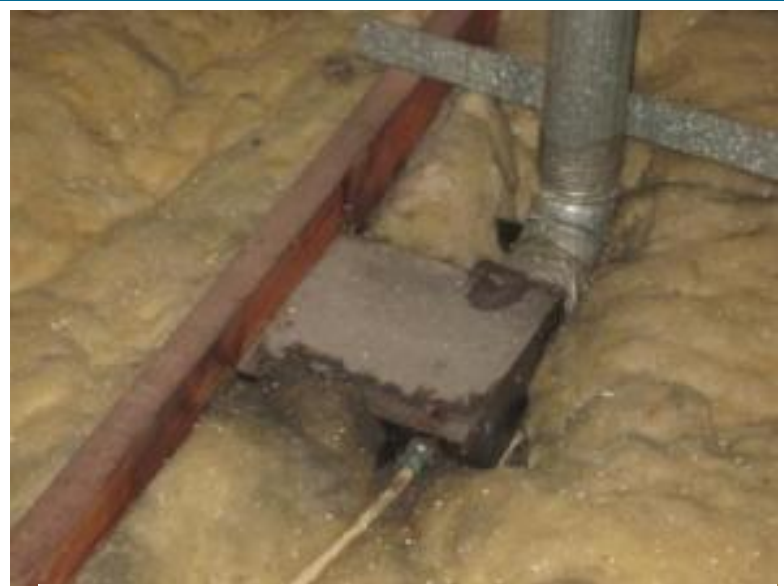

Leakage around bath fans is apparent from stained fiberglass

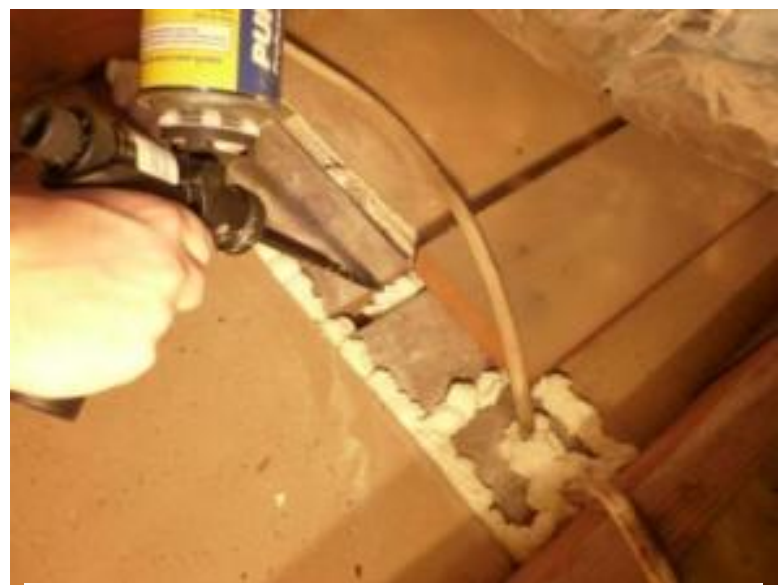

Top plates between rooms allow air from wall cavities to escape

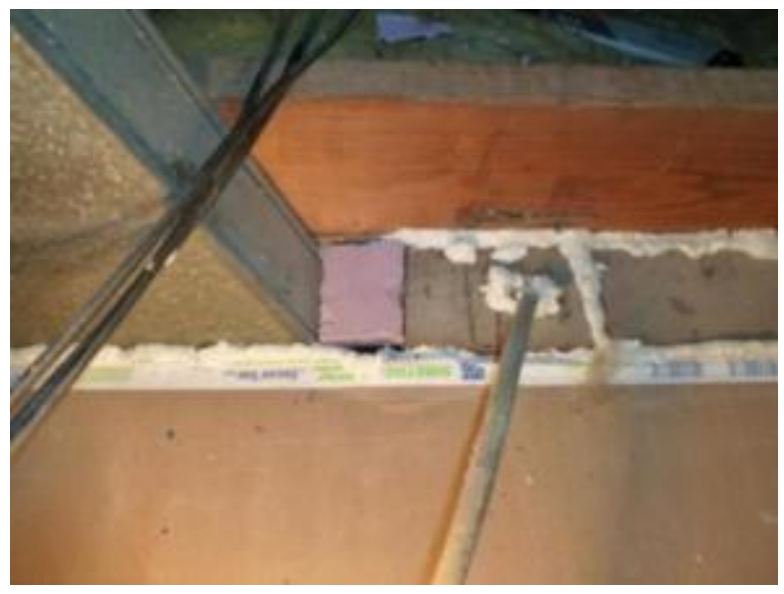

Spray foam seals smaller gaps and pieces of rigid board bridge larger gaps

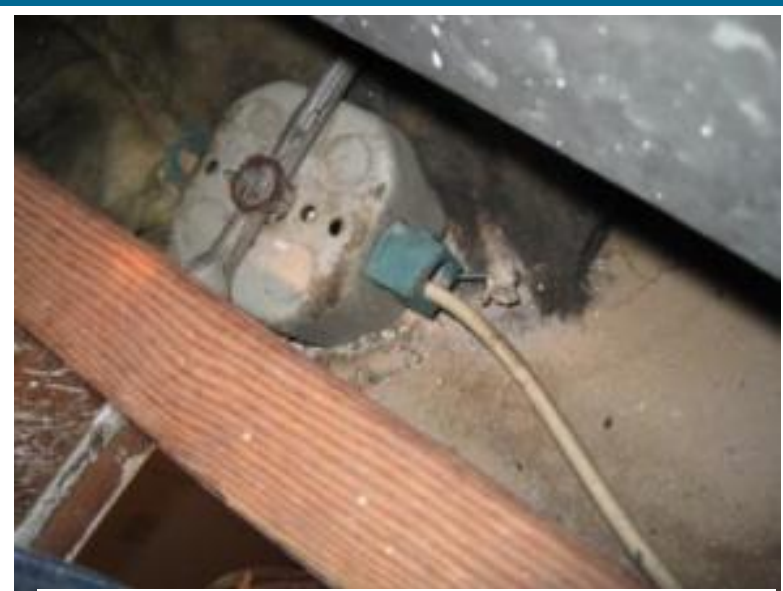

Electrical penetrations abound

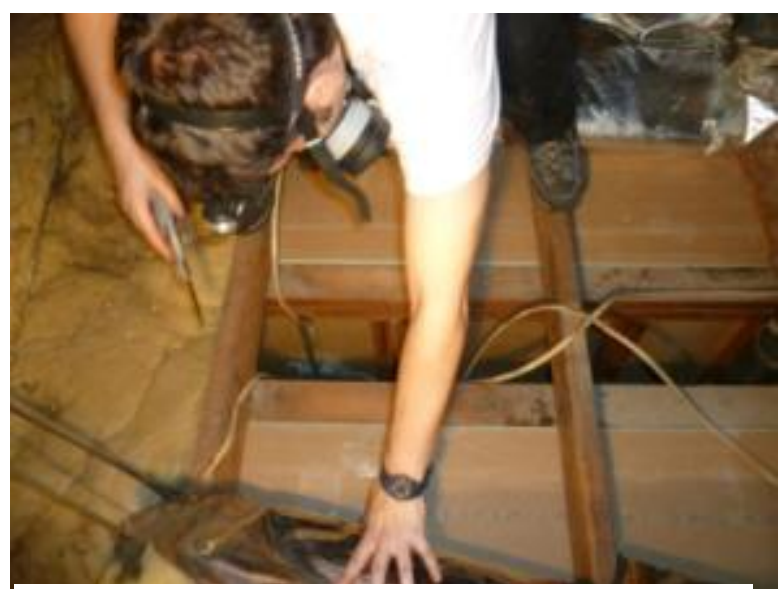

Large soffits and plumbing walls are wide open to the attic

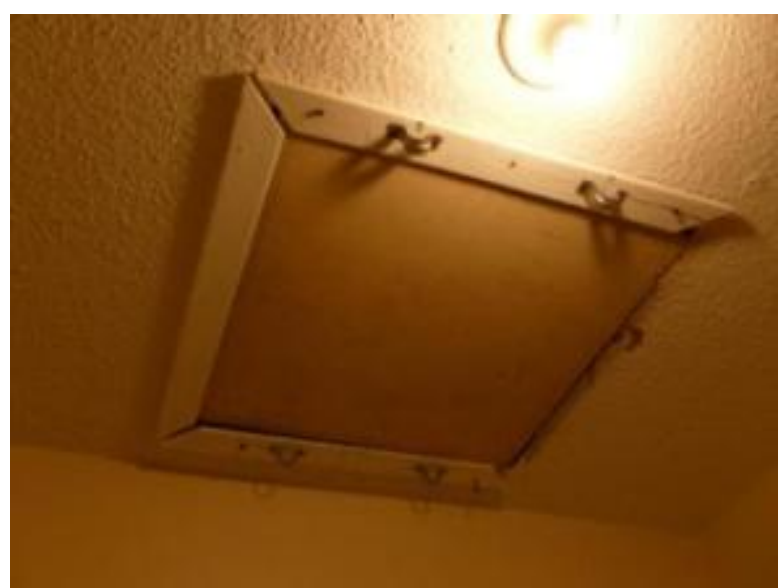

Attic hatches will receive weather-stripping and latches to hold them tightly closed

Figure 44. Addressing various attic leaks found in low-rise multifamily buildings 


\subsection{Mid-Rise Masonry Building}

This mid-size apartment building dates from the 1920s, and is typical of many older apartment buildings. The roof and ceiling are framed with dimensional lumber; the roof cavity is intentionally ventilated. No insulation is currently installed. A shallow crawlspace provides the only access to perform air sealing work. Although the necessary air sealing tasks are similar to those for single-family homes, they are complicated by the lack of access and limited space in which to work.
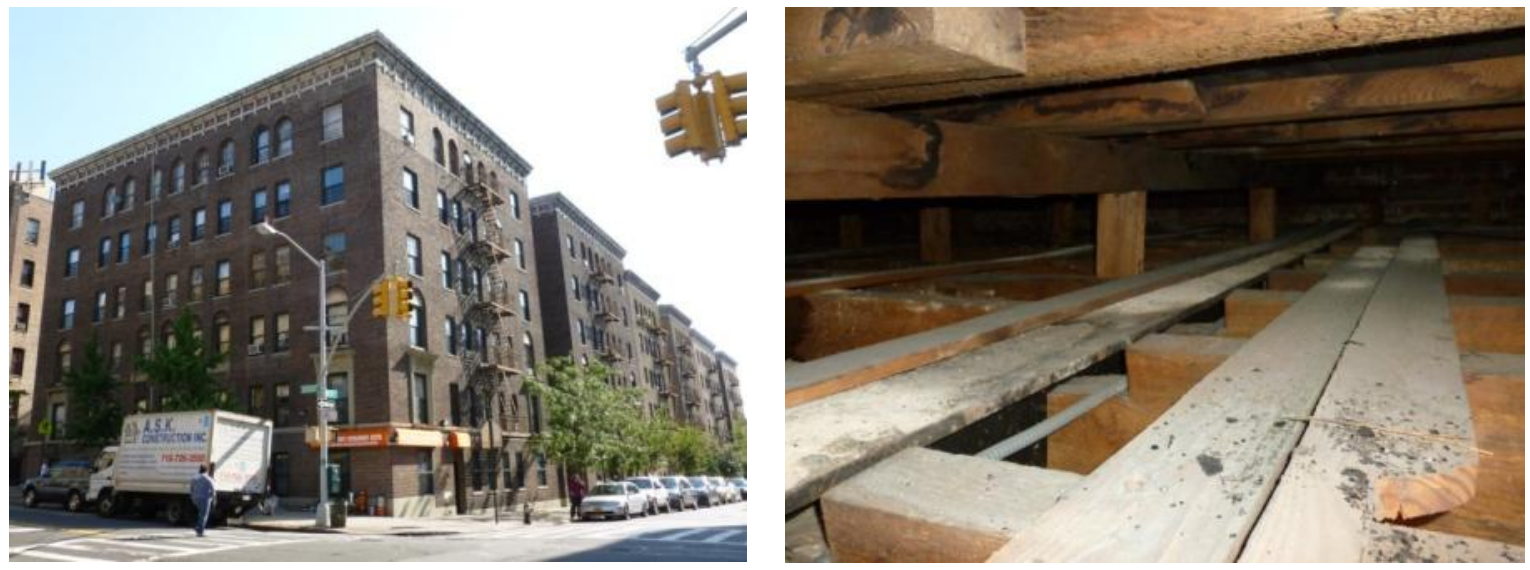

Figure 45. Attic space typical of this type of building

Identified Challenges:

There are a variety of gaps that recur many times:

1. Ceiling/wall junction

2. Demising wall top plates

3. Electrical Penetrations

How to Retrofit:

This type of building is more difficult than many other types of buildings, mainly due to the limited access. It is necessary to cut numerous access holes to allow workers to enter the roof cavity. Working from the roof cavity, workers should seal all gaps with expanding foam and barrier boards as appropriate. It is important to seal all gaps before installing insulation to maximize energy savings and reduce the risk of moisture problems developing in the cavity.

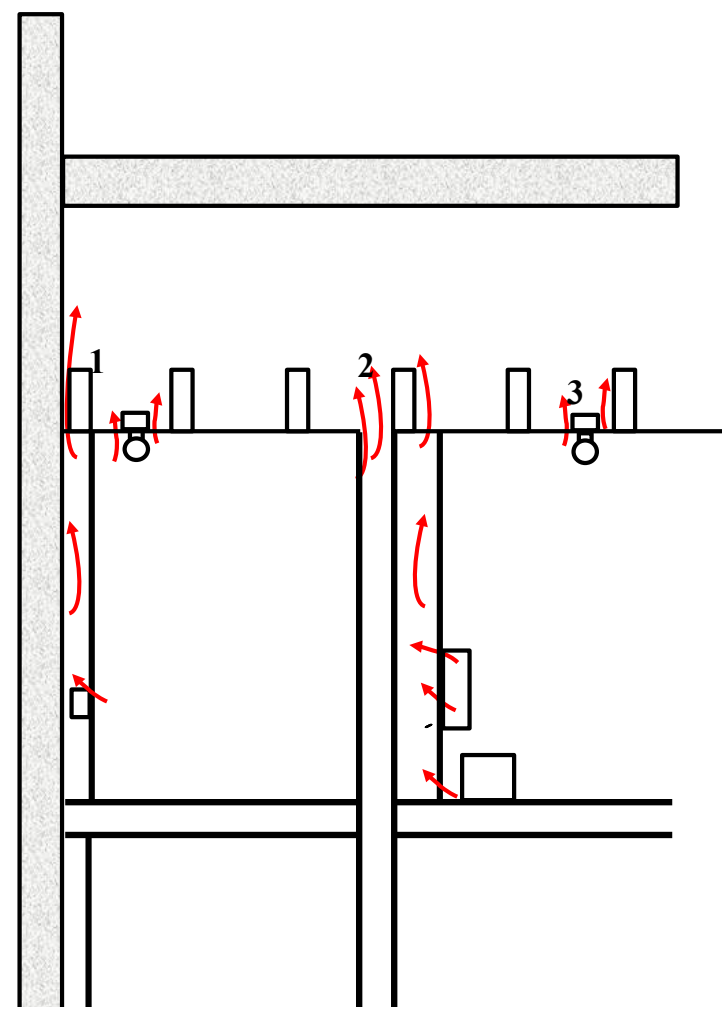




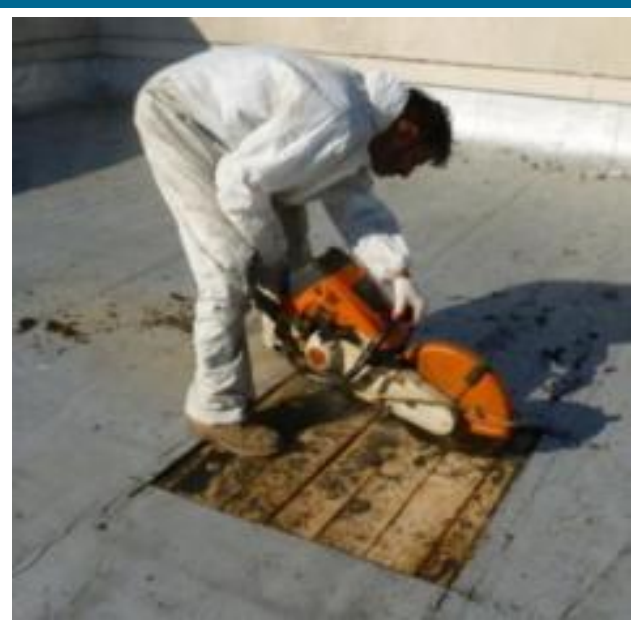

Access holes must be cut to access the attic

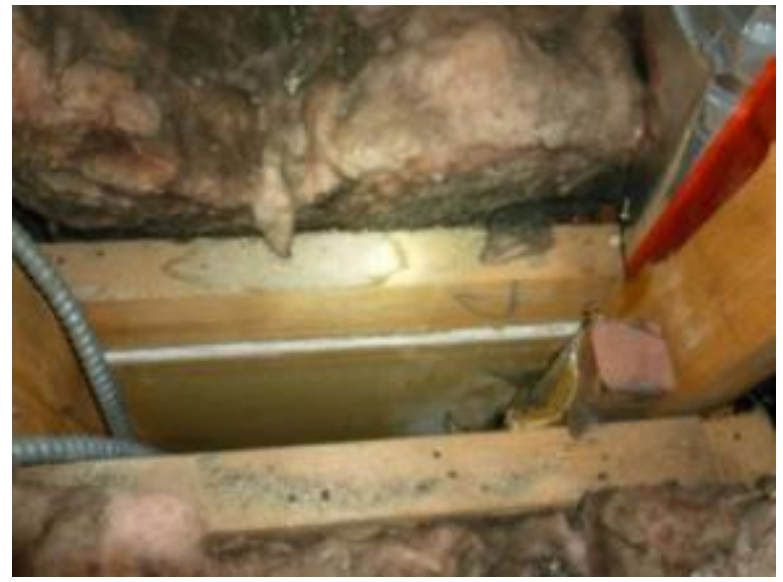

No top plates between some rooms allow air from wall cavities to escape

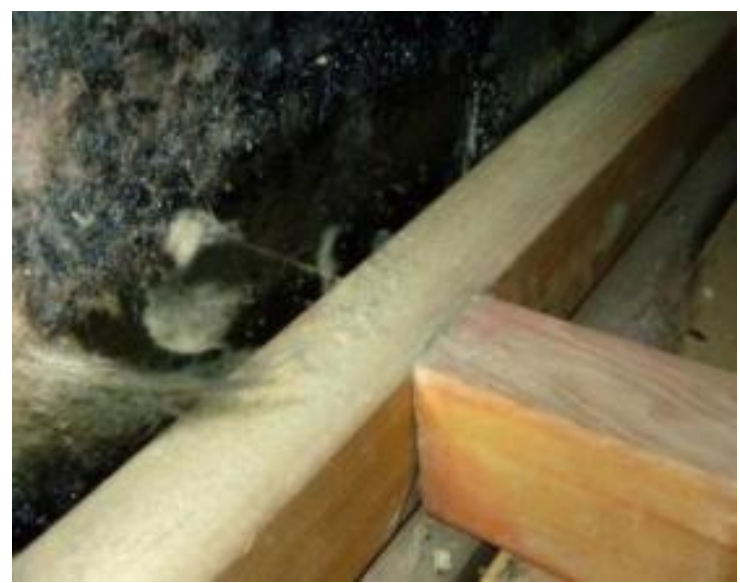

The gap between the exterior masonry wall and wall furring/ceiling must be sealed

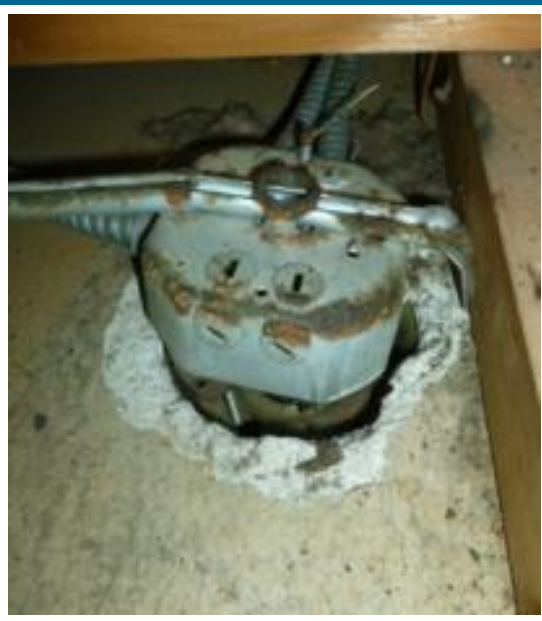

Junction boxes for lights can be quite leaky

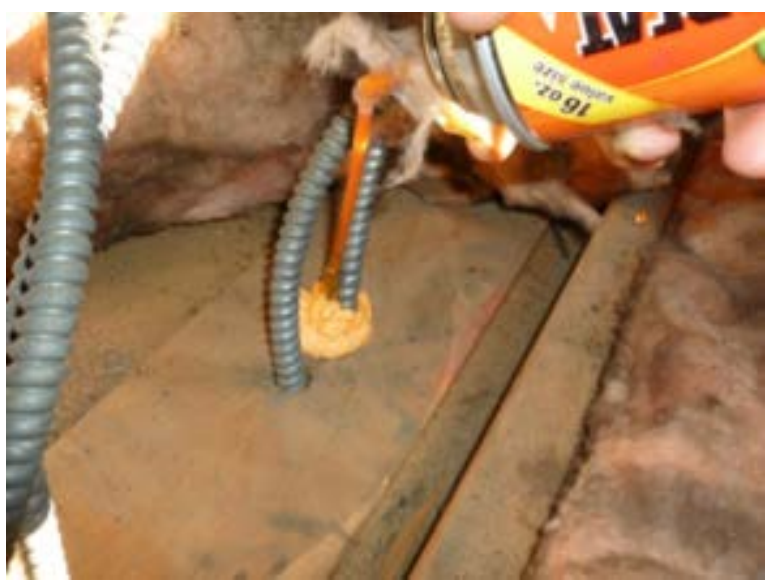

Numerous electrical penetrations contribute to leakage

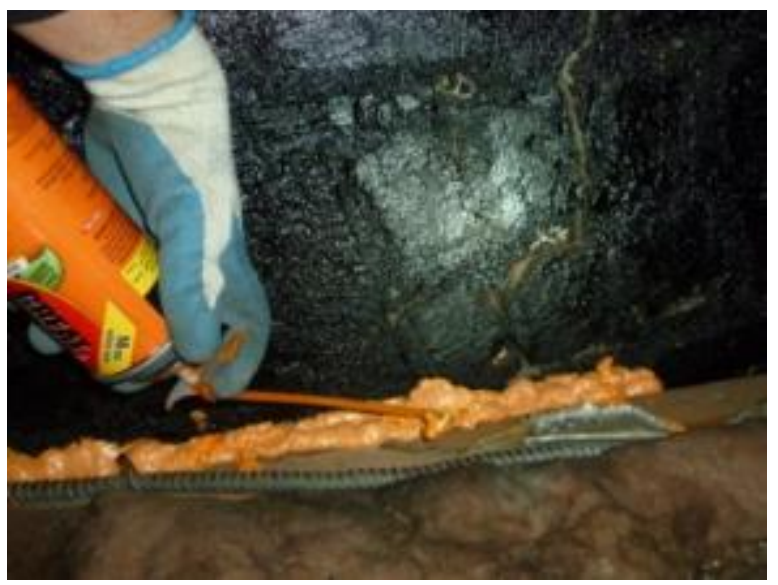

Expanding foam quickly seals the gap at the exterior wall

Figure 46. Accessing the attic through the roof deck to perform air sealing 


\subsection{High-Rise Apartment Building}

In high-rise buildings, the definition of "attic" is sometimes not straightforward. In this large multifamily building, a space between the top floor apartments and the roof deck can be considered an attic.
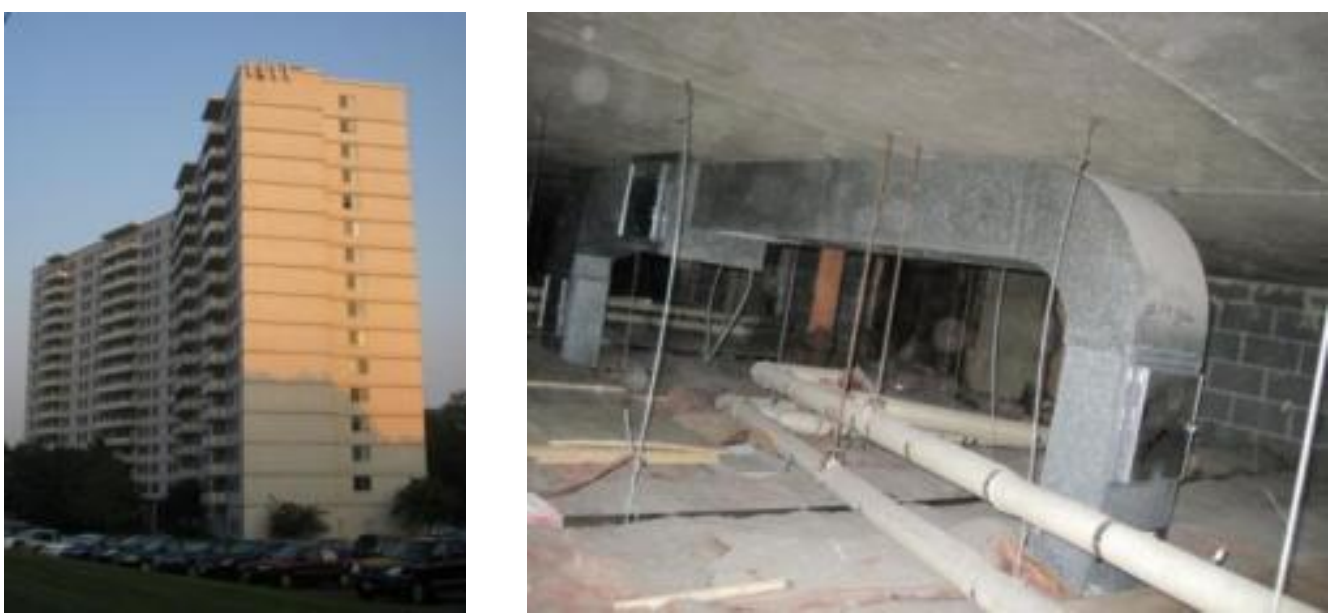

Figure 47. A 17-story multifamily building with large attic space

The attic space in this building is approximately four feet tall and is located between the underside of the concrete roof slab and the suspended drywall/plaster ceiling of the top floor apartments. The attic is not intentionally ventilated. The walls of the attic space are CMU faced with brick on the exterior. There are a number of roof fans that ventilate the apartments. The ductwork for these fans passes through the attic, creating a large number of penetrations and bypasses.

\section{Identified Challenges:}

The attic has not been well air-sealed, and there is significant opportunity to reduce infiltration. The main air sealing opportunities in this building include:

1. Bypasses around the trash chute and ventilation ducts

2. Electrical and plumbing penetrations

3. Soffits in apartment kitchens and bathrooms

4. Apartment demising and exterior wall top plates

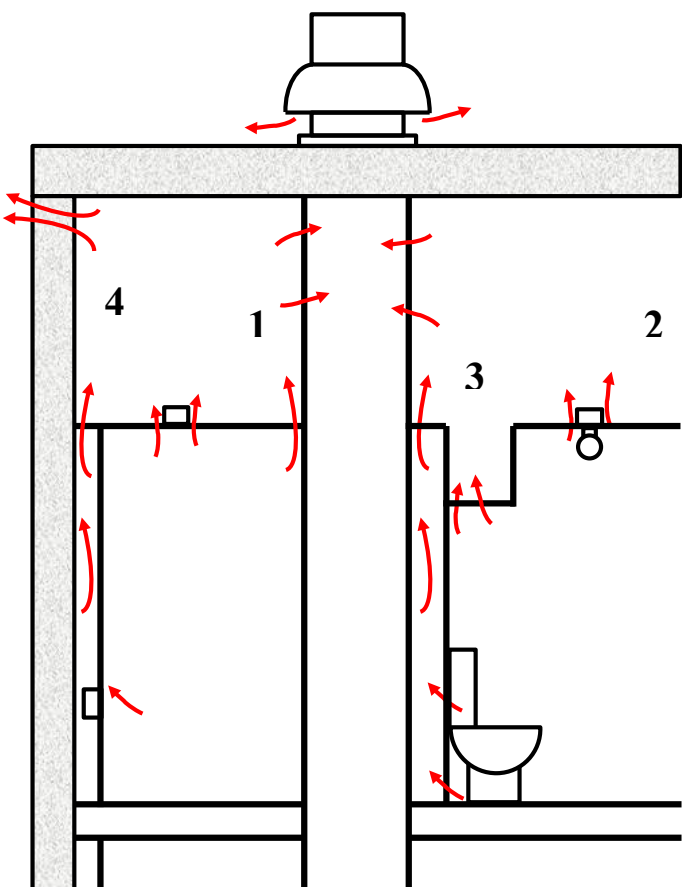




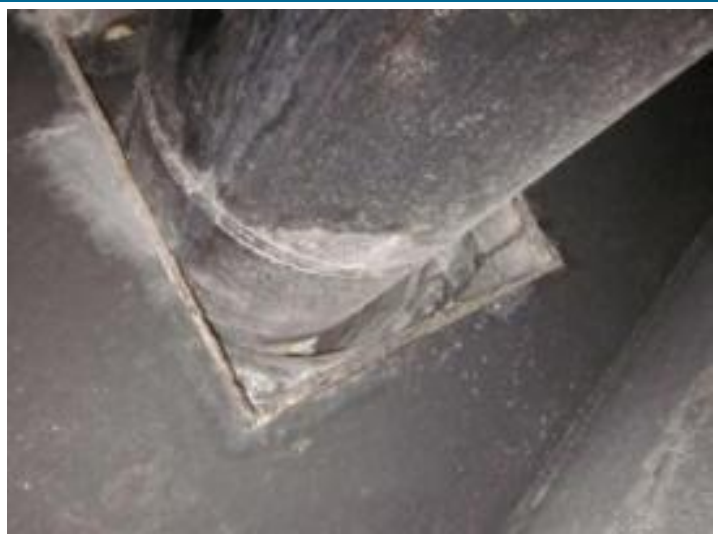

Large gap around the trash chute

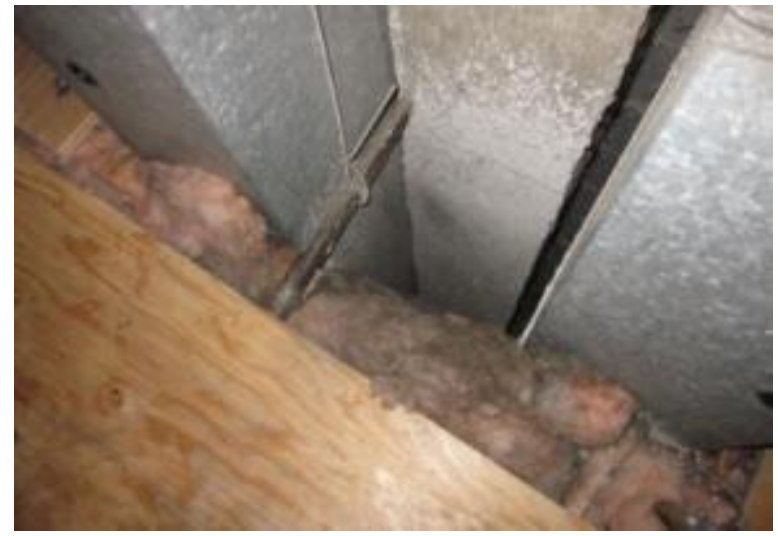

Chases around duct work

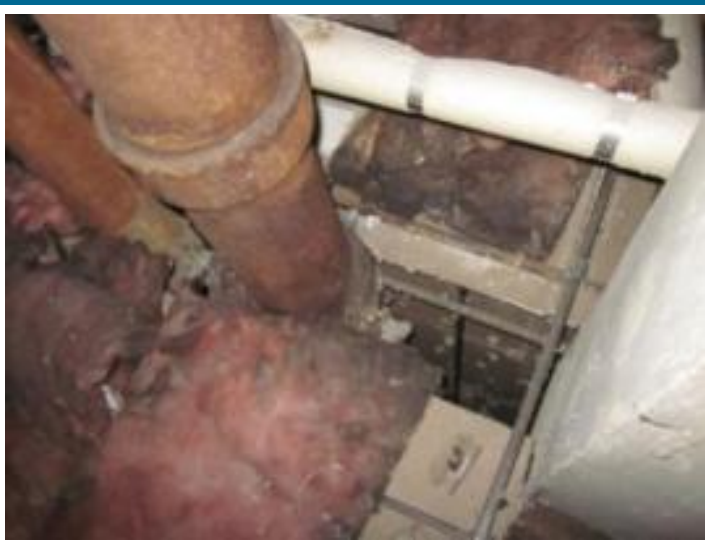

Numerous plumbing chases

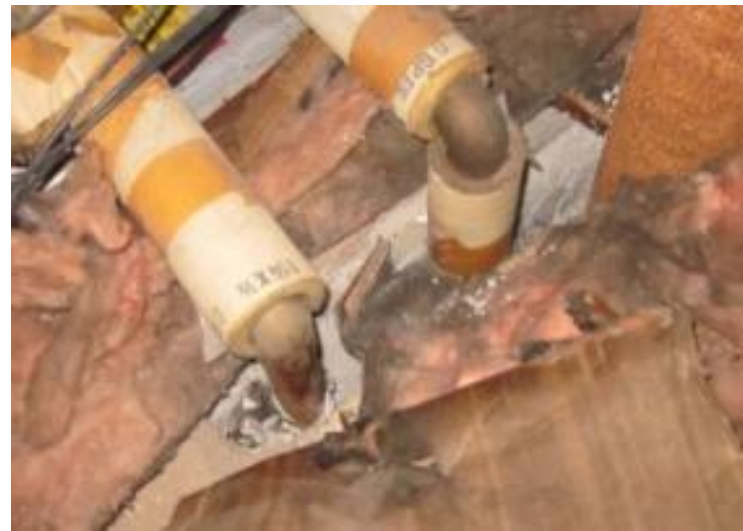

Pipe penetrations into living space

Figure 48. Various air bypasses that where found during the attic inspection

How to Retrofit:

The first task is to define the location of the air barrier. In this building, the best location is at the ceiling of the top floor apartment. This is where the insulation layer is currently located, and it is best to keep the air barrier aligned with the thermal barrier. Though the roof deck would make a superior air barrier, there are no plans to replace the roof membrane in the near future, and so insulating the roof itself will not happen for some time. Because of easy access to the attic in this building from the corridors, it would be possible to perform air sealing work at any time while minimizing disruption to tenants. All of the problems identified here could be addressed easily using one-part expanding polyurethane foam, barrier boards and appropriate caulks. Issues to remember include avoiding damage to the ceiling, which may require creating temporary catwalks to distribute the weight of workers. 


\section{Appendix A: Measure Implementation Checklist}

The nature and scope of multifamily attic air sealing and insulating efforts can vary substantially. Based on these guidelines, the checklist below is presented as a potential framework for conducting air sealing efforts.

1. Inspect the building for significant risks. Are any of the following present?

\begin{tabular}{|l|l|l|}
\hline Structural problems & Yes & No \\
\hline Exposed or knob and tube wiring & Yes & No \\
\hline Severe water damage & Yes & No \\
\hline Mold & Yes & No \\
\hline Asbestos or other toxic materials & Yes & No \\
\hline Incorrect ventilation of roof cavity & Yes & No \\
\hline Ventilation ducts terminating in attic & Yes & No \\
\hline Erratic or dangerous occupants & Yes & No \\
\hline
\end{tabular}

If the answer is "Yes" to any of these or if other serious risks are identified, do not proceed with work until the risks have been addressed.

2. Assess the accessibility of the roof cavity. Use appropriate inspection methods to determine how to best inspect the attic. Options for inspecting the attic include:

- Remote inspection using a borescope

- Cutting access holes in the ceiling

- Cutting access holes in the roof

- Infrared thermography.

3. Inspect the attic for health and safety and other risks and air sealing locations. Perform a complete inspection of the attic, looking for all risks mentioned above, as well as:

- Combustion appliances or vents from combustion appliances

- Evidence of condensation

- Recessed lights which are not rated for insulation contact

- Framing or ceiling construction that is not adequate to safely support workers.

4. Determine where to establish the air barrier. In existing buildings it is often most straightforward to perform air sealing and insulating work at the ceiling plane, however this will vary depending on venting requirements, construction type, and other work being performed at the time. Identify all locations in need of air sealing and select appropriate materials and methods to perform work.

5. Perform air sealing work. Using appropriate materials, perform air sealing work.

6. Inspect the attic to ensure that air sealing has not created any health or safety risks. 


\section{References}

ABAA. (2011). "About Air Barriers.” Air Barrier Association of America. Accessed January 2, 2012. http://www.airbarrier.org/about/materials e.php.

BECRC. (2009). "What are the requirements for recessed cans in the energy code?" Building Energy Codes Resource Center . Accessed January 3, 2012

http://resourcecenter.pnl.gov/cocoon/morf/ResourceCenter/article//112.

CMHC. (2007). "Air Leakage Control Manual Existing Multi-Unit Residential Buildings.” Canada Mortgage and Housing Corporation. Accessed January 2, 2012. https://www03.cmhcschl.gc.ca/catalog/productDetail.cfm?cat=123\&itm=69\&lang=en\&fr=1325534182081.

NREL. (2010). "National Residential Efficiency Measures Database: Retrofit Measures for Air Sealing." National Renewable Energy Laboratory. Accessed January 2, 2012. http://www.nrel.gov/ap/retrofits/measures.cfm?gId=1\&ctId=1.

Building Science Corporation. (2010). “Guide to Attic Air Sealing.” Accessed January 16, 2012. http://www.buildingscience.com/documents/guides-and-manuals/gm-attic-air-sealing-guide.

Pacific Northwest National Laboratory. (2010). Building America Best Practice Series: Volume 10. "Retrofit Techniques \& Technologies: Air Sealing - A Guide for Contractors to Share with Homeowners.” Accessed January 16, 2012.

http://apps 1.eere.energy.gov/buildings/publications/pdfs/building_america/ba_airsealing_report. pdf. 


\section{U.s. DEPARTMENT OF Energy Efficiency \& ENERCY Renewable Energy}

